\title{
Dáfnis e Cloé, de Longo de Lesbos - Livro Primeiro: Tradução
}

\section{The Greek novel Daphnis and Cloe: a Portugues translation with study and notes}

\author{
Luiz Carlos André Mangia Silva*
}

\section{Apresentação}

O romance intitulado Dáfnis e Cloé, de Longo de Lesbos (cerca de II d.C.), é a obra única desse autor do qual nada se sabe. Dos cinco romances gregos de amor que nos chegaram integralmente (os chamados Big Five), ele é o único que faz uso tanto das fórmulas rapidamente percebidas nos romances antigos - no esquema narrativo, na mescla dos mais variados gêneros literários - quanto daquelas próprias da poesia grega de tema erótico e pastoril.

O romance é composto de quatro livros, informação que consta já no proêmio preparado pelo autor - proêmio, aliás, que exibe um autor muito consciente do registro que apresenta, ao anunciar a divisão da narrativa, seus principais temas, fazer uma invocação ao deus, propor o público e os objetivos aspirados pela obra, além de cruzar o tema da escrita com o da pintura: o autor nos informa que foi a contemplação de uma pintura magnífica que o motivou a escrever o livro.

Em língua portuguesa, dispomos apenas de tradução indireta do romance, feita a partir do francês. Esta passa por ser a primeira tradução feita do grego que pretendemos completar em breve. Para o texto grego, baseei-me na edição de Rudolf Hercher (LONGUS, 1858) (disponível em Perseus Digital Library), que cotejei com a de George Thornley e John Maxwell Edmonds (LONGUS, 1916). Para além de uma pequena disputa de vocabulário, as edições divergem ocasionalmente quanto à pontuação: a edição de Hercher prefere ponto alto (pausa forte) onde a edição da Thornley-Edmonds prefere vírgulas (pausa fraca); outras vezes, onde Hercher coloca pontuação, Thornley-Edmonds preferem texto corrido, sem vírgula ou ponto final. Esse fato me permitiu decidir, em alguns casos, qual a relação estabelecida entre as orações se de estreita dependência ou não. Segui, todavia, do começo ao fim a edição de Hercher, salvo para a primeira frase do Proêmio, que aparece lacunar nesta edição, mas completa na de Thornley-Edmonds.

Consultei em detalhe a tradução espanhola de Máximo Brioso Sánchez e Emilio Crespo Güemes (LONGO, 1997), bastante fiel ao original grego, e a portuguesa, feita a partir do francês, de Duda Machado (LONGUS, 1996). Em certos passos, compulsei também a inglesa de Thornley-Edmonds. Com isso pude medir o grau de acerto de muitas decisões tradutórias, bem como me distanciar deliberadamente das decisões alheias, sobretudo em relação ao vocabulário. Mas é claro que foi nos passos mais difíceis do texto grego que tais edições (sobretudo a espanhola e a inglesa) socorreramme, orientando a mais correta interpretação de frases e termos do original.

\footnotetext{
* Professor Adjunto da Universidade Estadual de Maringá (UEM) desde 2011. Possui Pós-Doutorado em Linguística (2009-2010 / UNESP), Doutorado (2004-2008 / UNESP) e Mestrado (2001-2003 / UNESP) em Estudos Literários, Bacharelado e Licenciatura em Letras (1997-2000 / UNESP).
} 
Mantive o mais possível a extensão das frases originais, obedecendo as pausas e os cortes de ideias aparentemente produzidos pelo autor. Assim, procurei manter as orações subordinadas ligadas às principais, só de vez em quando desdobrando-as em orações coordenadas. Nesse ponto, tem papel importante o uso do particípio verbal grego, por ser ele, na maioria das vezes, o elemento que constrói a subordinação: dinâmico, seu uso faz supor muitas vezes uma linguagem fluente, de primeiro plano, e não necessariamente de oração secundária, como previsto pelas gramáticas - daí que algumas vezes os particípios resultem, na tradução, em verbos no indicativo, que coordenei com as outras orações.

O tratamento dos tempos verbais gregos é outra questão: com relativa frequência, o autor faz uso do chamado presente histórico, seja em conjuntos de frases, seja apenas em uma forma verbal ou outra, embaralhada aos tempos do passado (imperfeito e aoristo, sobretudo). Para evitar grandes estranhamentos do leitor em vernáculo e erros tradutórios, procurei manter o tempo presente somente quando usado prolixamente, em conjuntos de frases. Quando utilizado apenas pontualmente, se causava estranhamento, preferi alinhá-lo aos tempos do passado. E, inversamente, quando em meio ao uso sistemático do presente verbal surgiu uma ou outra ocorrência de verbo no passado, traduzi tais formas pelo presente, privilegiando esta predominância.

A obra é bastante fluida e demasiado idealizada na pintura que faz do mundo pastoril. Ali tudo é divino e maravilhoso e inocente, embora a tranquilidade da vida camponesa seja por vezes quebrada pelo surgimento de perigos próprios ao contexto (melhor diria, próprios ao padrão romanesco). Dáfnis e Cloé são jovens irmanados pelo fato de terem sido crianças expostas na infância, amamentadas por cabra ele, ovelha ela, e criadas por pastores. No Livro Primeiro tem lugar o encontro dos bebês abandonados em Lesbos, o desenvolvimento dos dois que, adolescentes, ostentam uma beleza incomum no mundo pastoril, o sonho dos pais que lhes anuncia o destino de guardadores de rebanhos, a alegria com que eles assumem suas tarefas, os perigos da vida no campo na presença de lobos e piratas, as primeiras emoções amorosas, a investida de um rival, enamorado de Cloé, a incapacidade dos jovens de nomear os sentimentos contraditórios que os acometem. Essas são, entre outras, as ações que o leitor poderá conhecer nas linhas que seguem.

\section{Texto original}

\section{LIVRO PRIMEIRO}

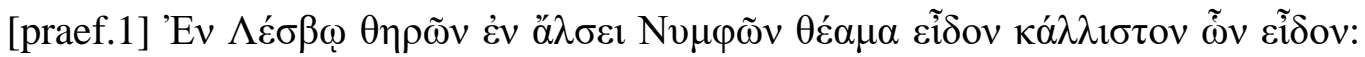

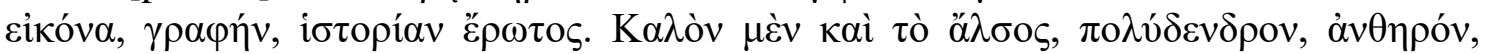

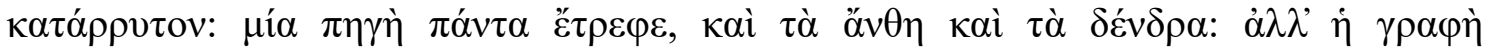

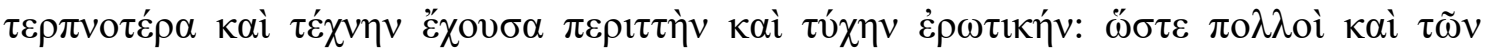

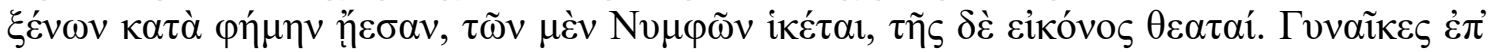

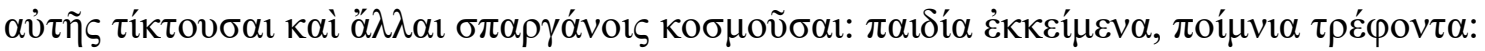

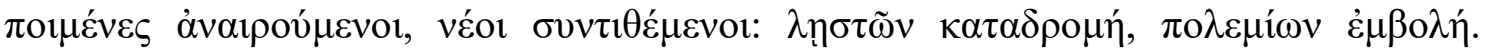

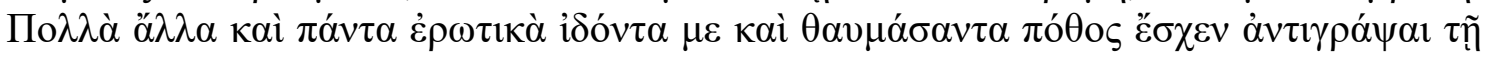

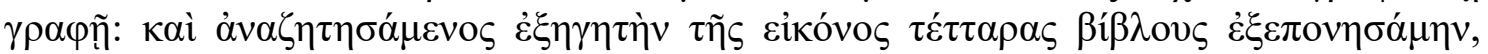

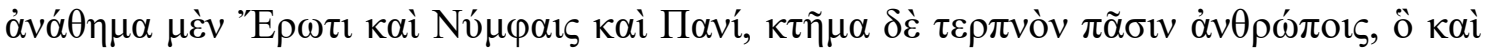

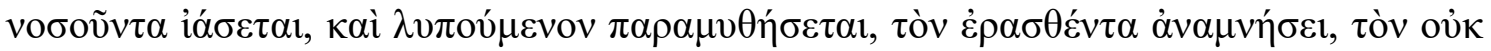

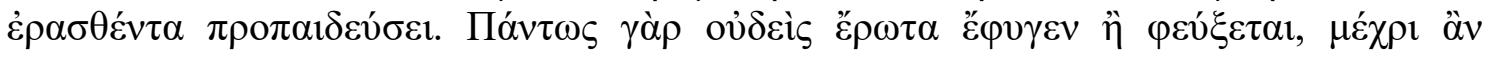




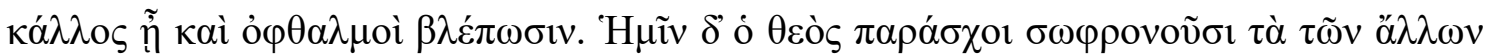

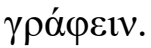

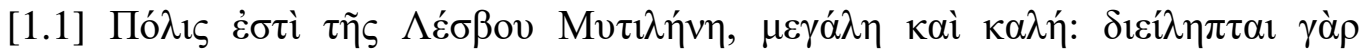

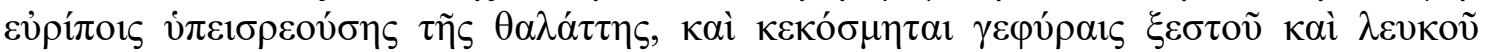

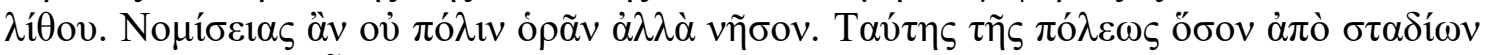

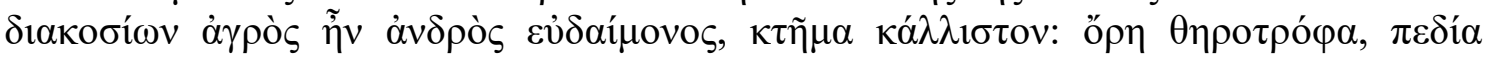

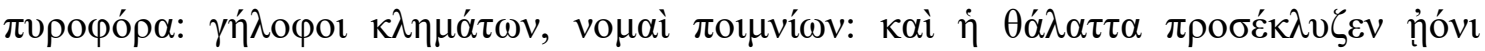
$\dot{\varepsilon} \kappa \tau \varepsilon \tau \alpha \mu \dot{\varepsilon} v \eta ฺ, \psi \alpha ́ \mu \mu \omega \mu \alpha \lambda \theta \alpha \kappa \tilde{n}$.

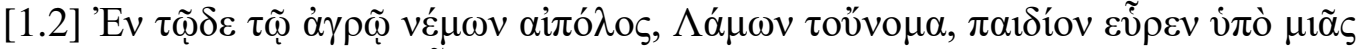

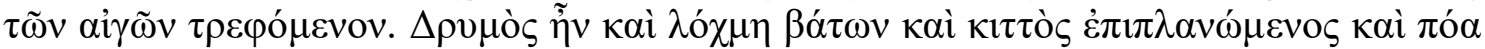
$\mu \alpha \lambda \theta \alpha \kappa \eta ́, \kappa \alpha \theta$ '

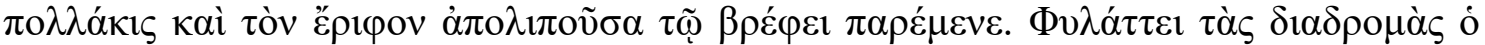

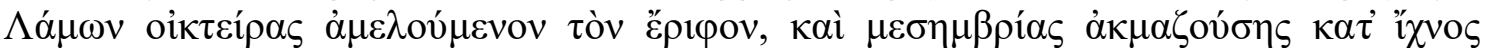

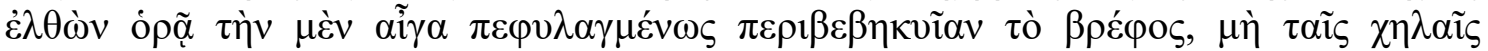

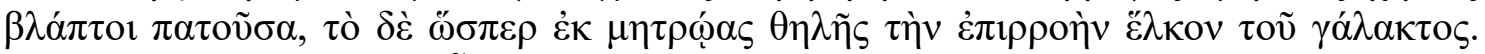

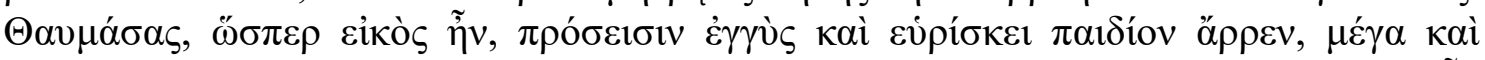

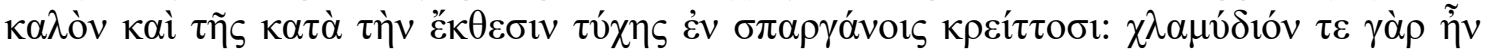

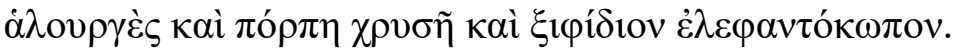

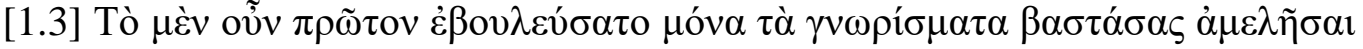

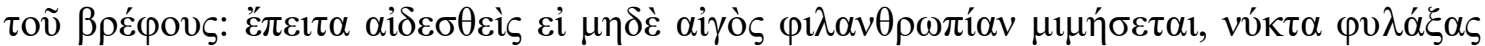

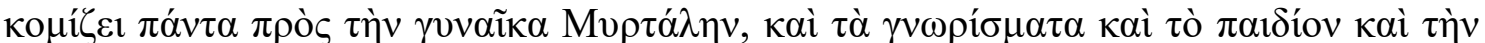

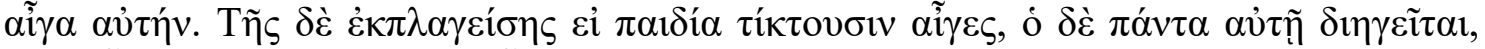

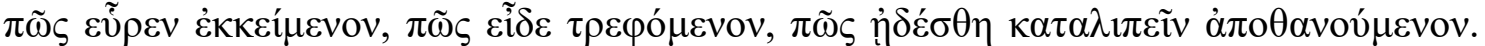

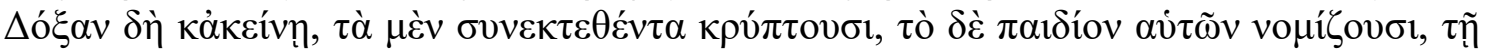

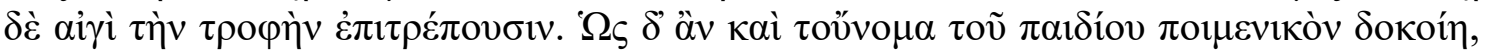

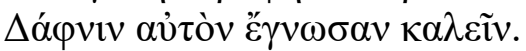

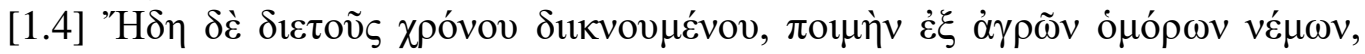

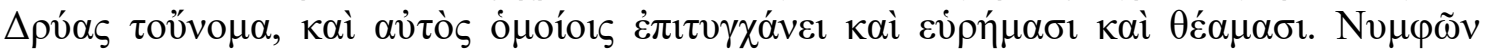

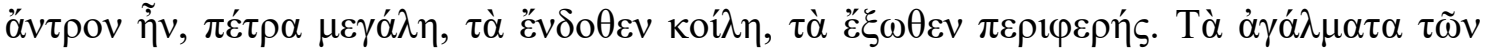

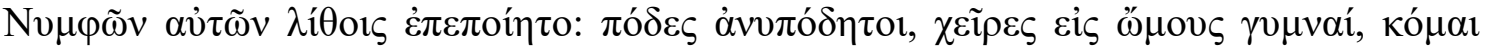

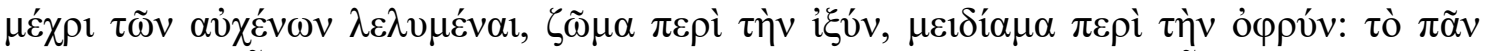

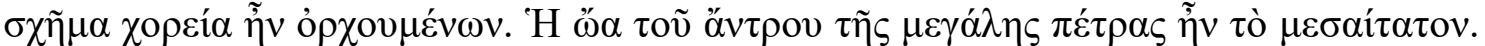

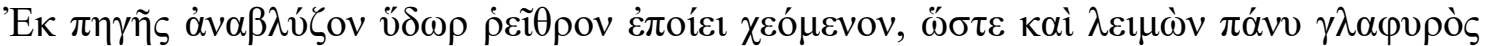

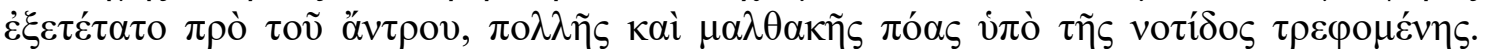

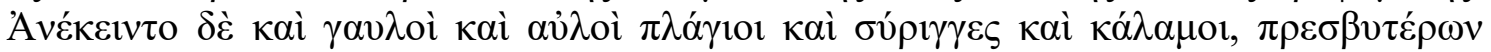
$\pi 01 \mu \varepsilon ́ v \omega v \dot{\alpha} v \alpha \theta \eta \dot{\eta} \mu \alpha \tau \alpha$.

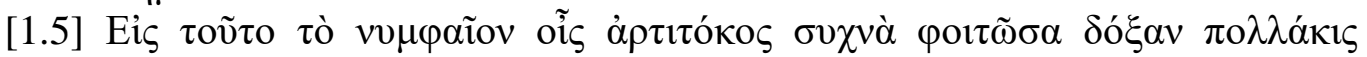

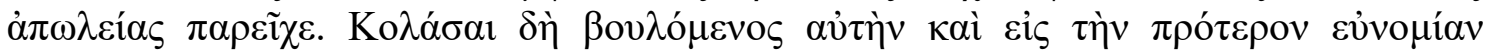

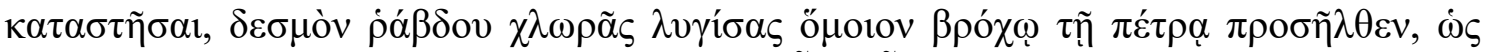

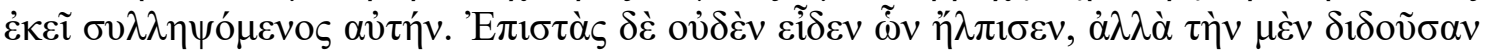

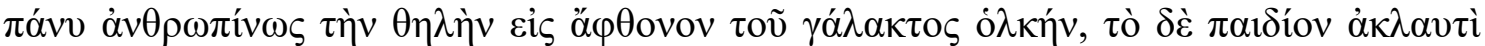

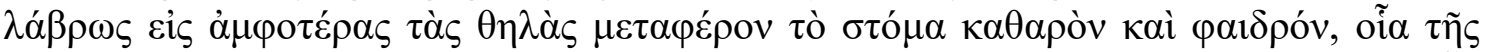

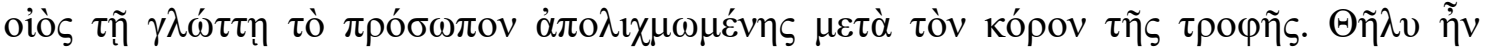

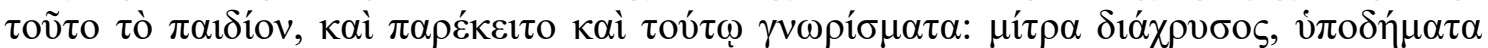

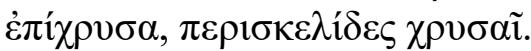

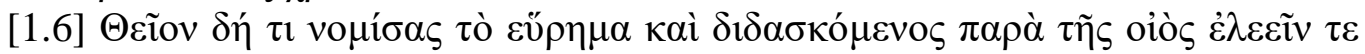

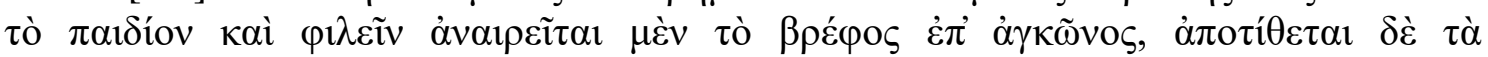

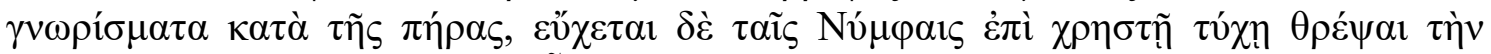

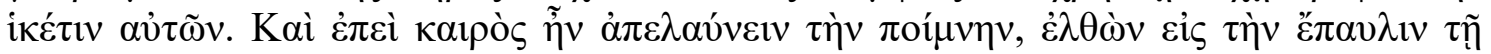




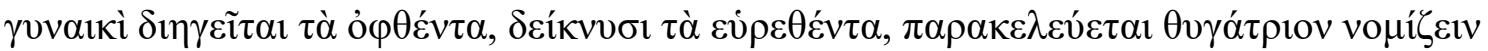

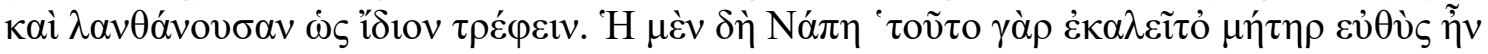

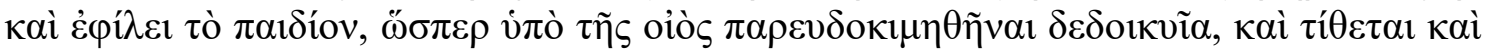

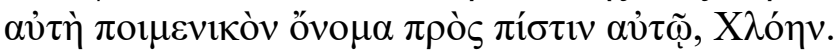

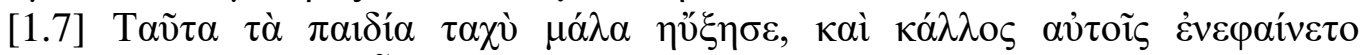

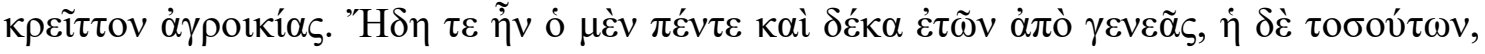

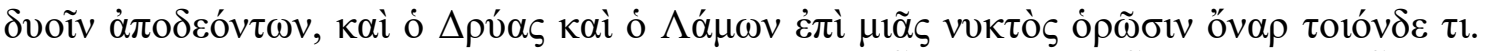

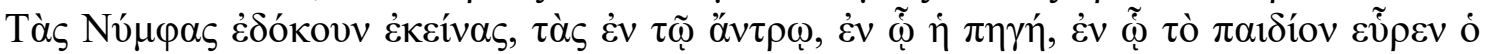

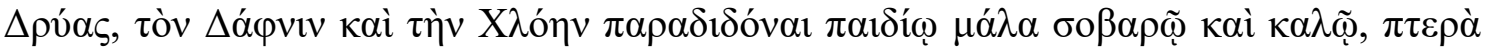

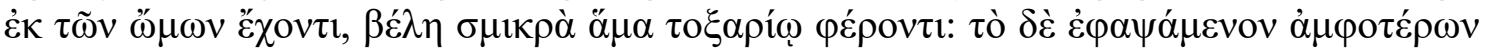

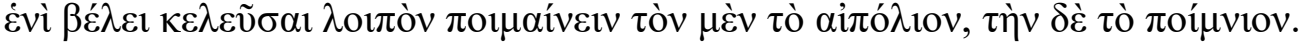

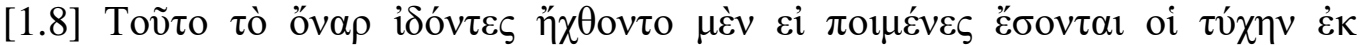

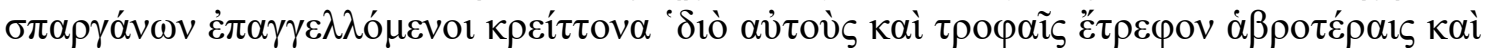

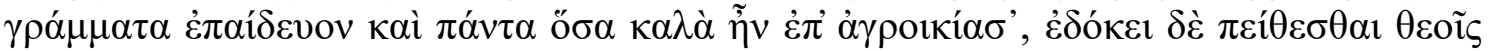

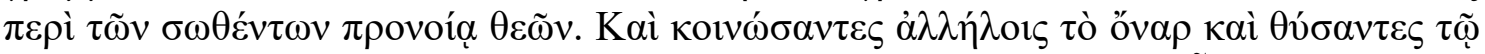

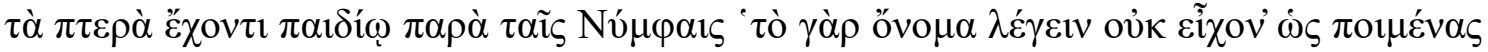

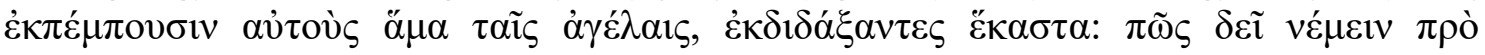

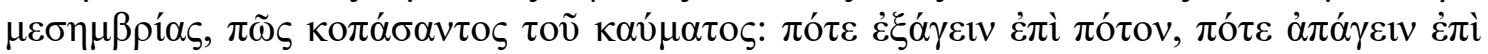

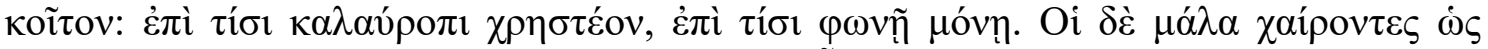

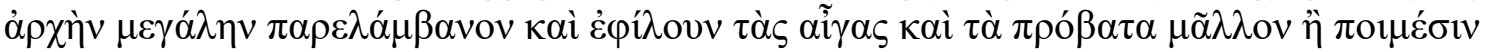

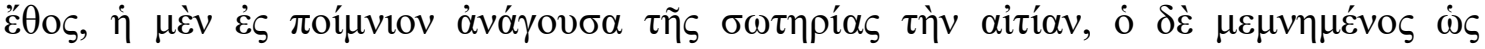

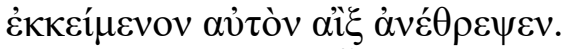

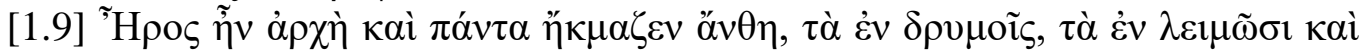

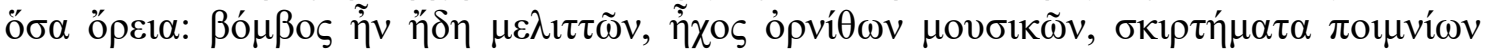

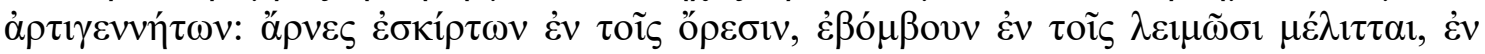

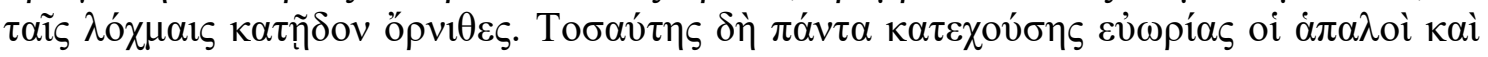

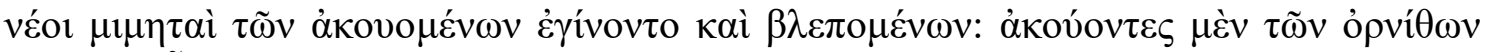

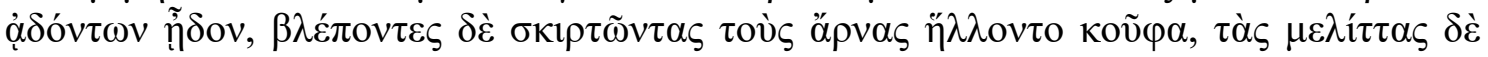

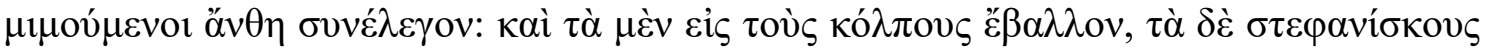

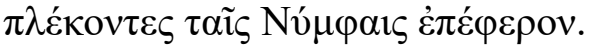

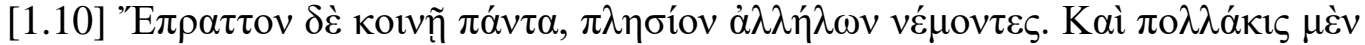

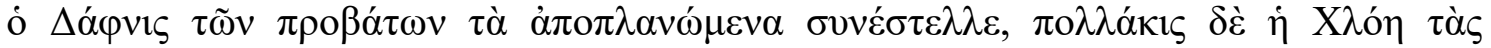

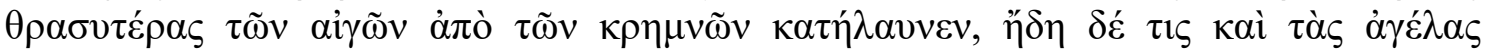

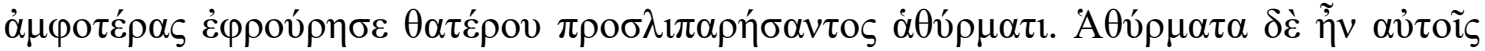

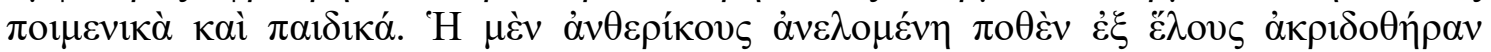

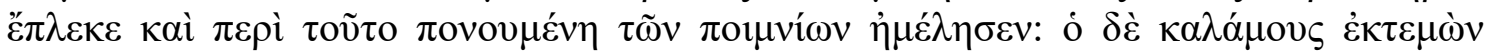

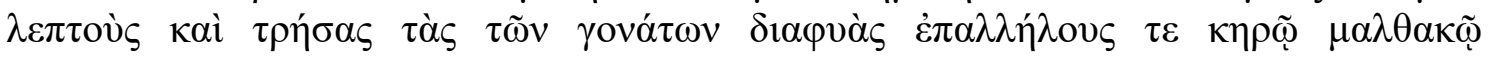

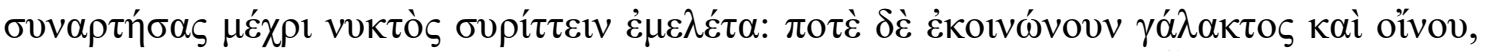

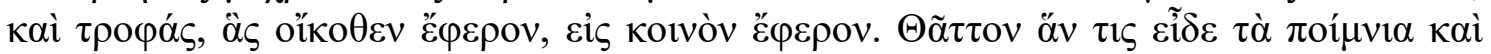

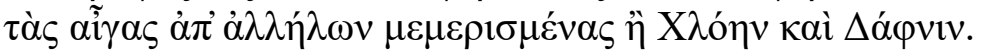

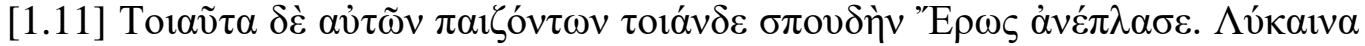

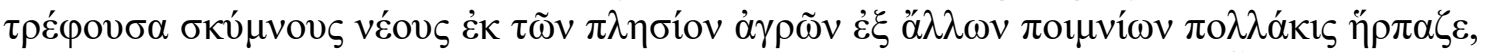

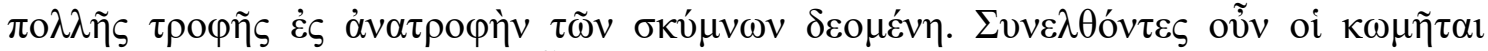

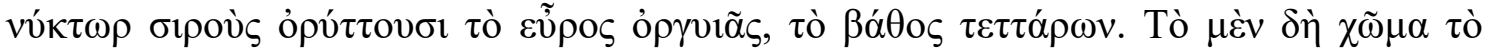

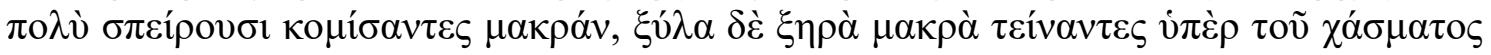

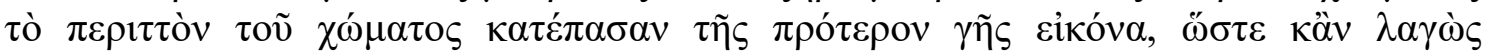

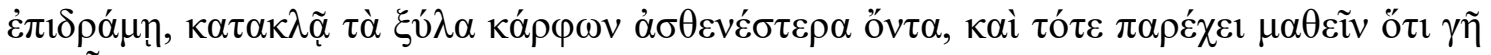

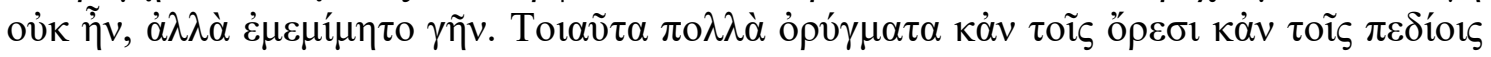




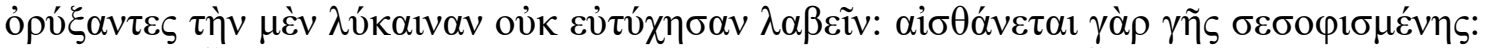

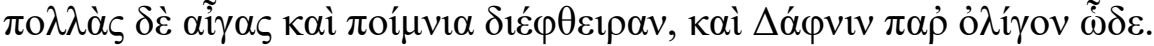

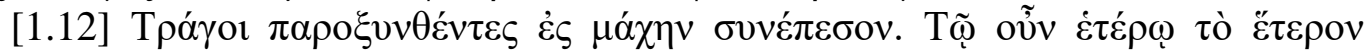

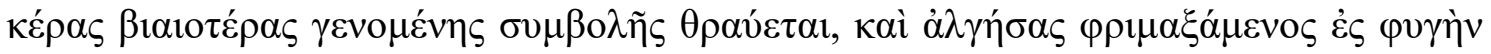

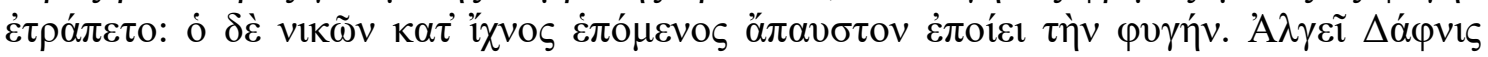

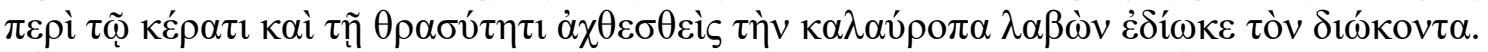

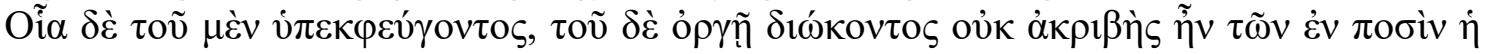

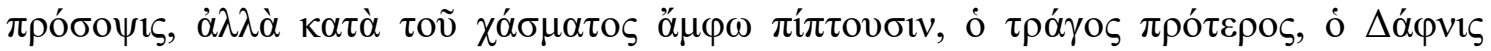

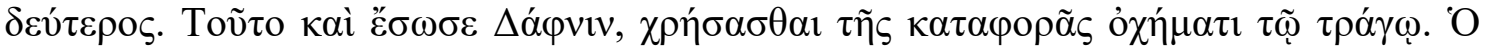

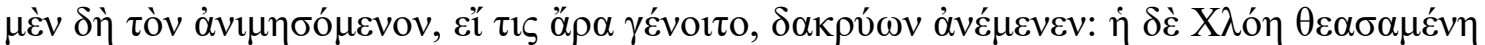

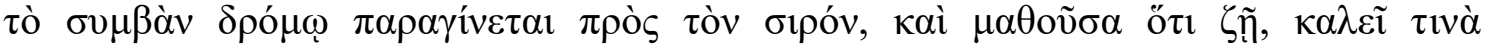

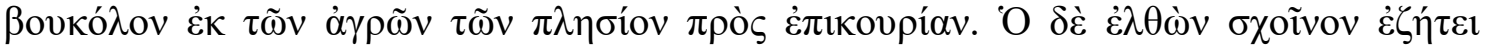

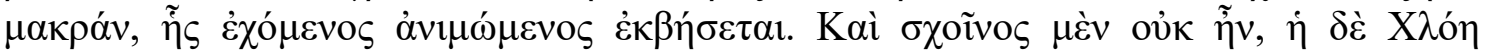

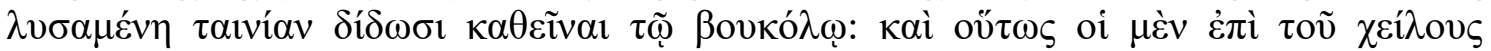

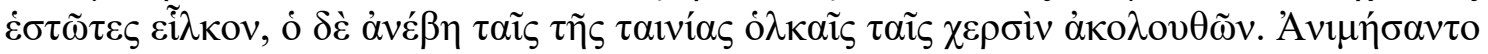

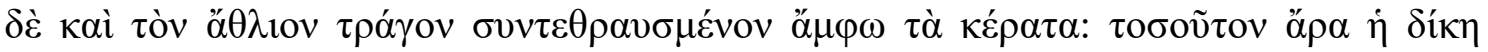

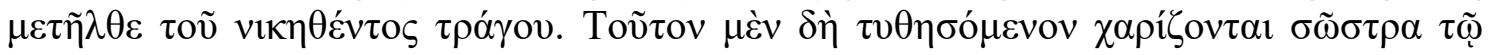

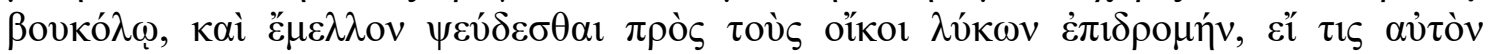

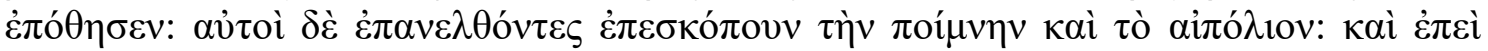

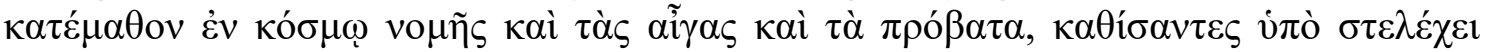

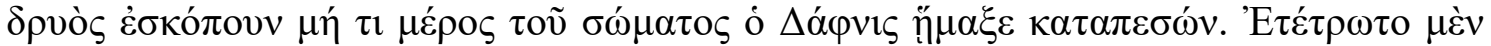

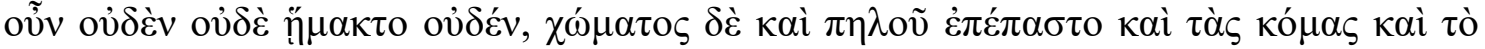

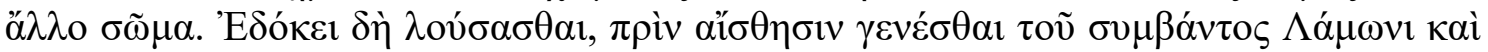

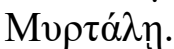

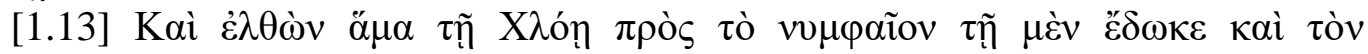

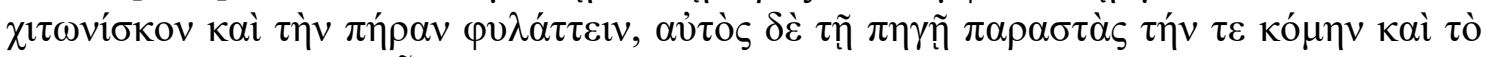

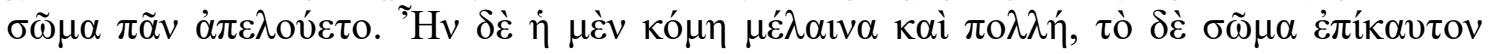

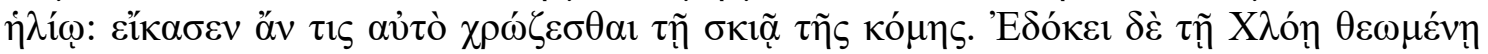

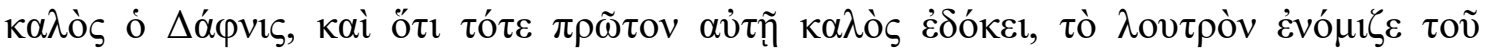

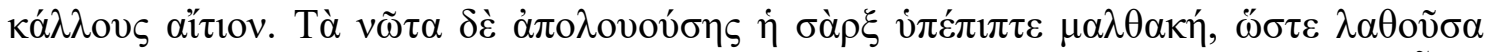

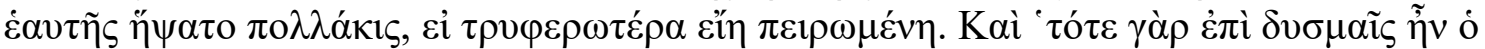

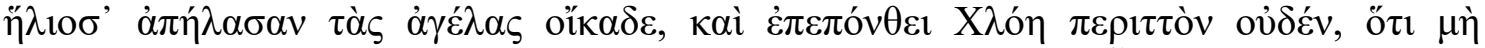

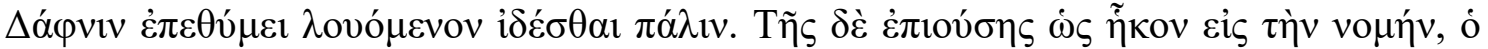

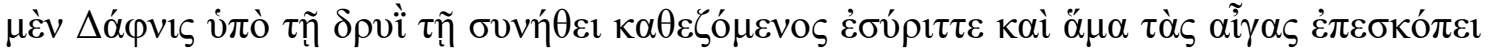

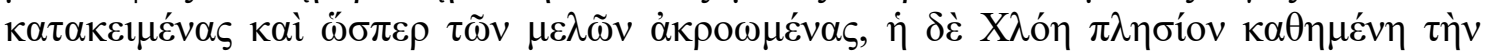

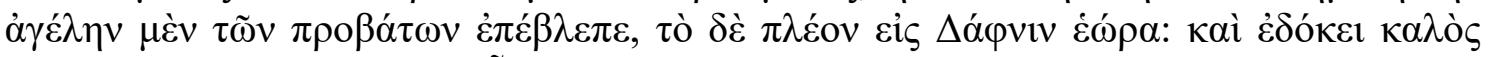

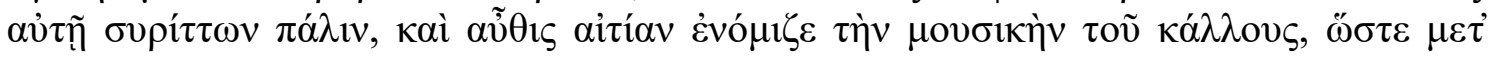

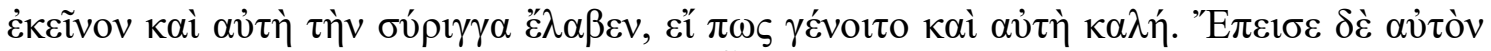

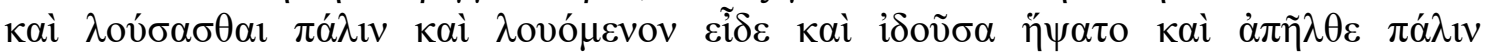

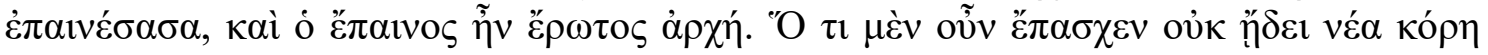

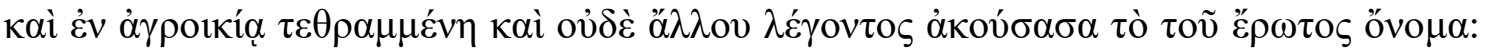

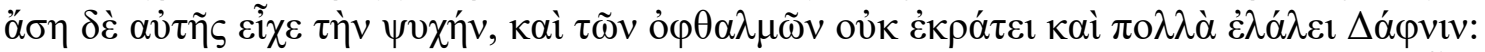

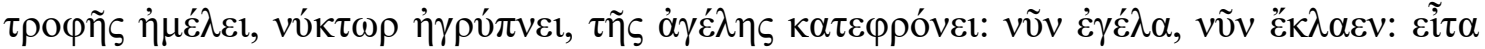

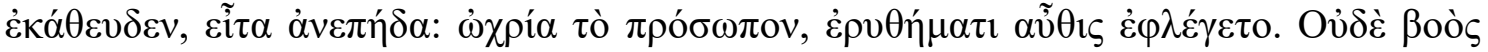

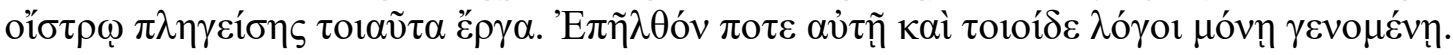

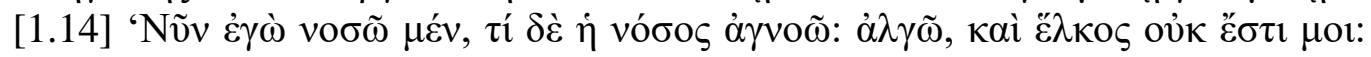

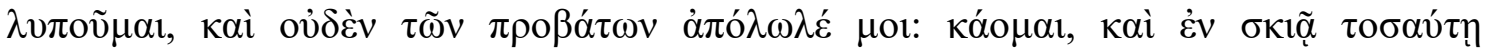

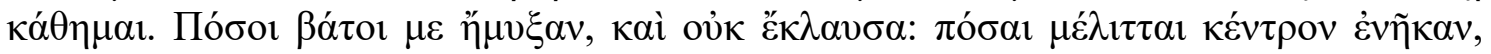

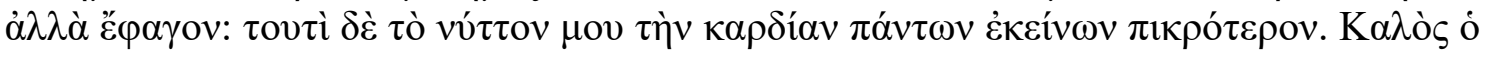




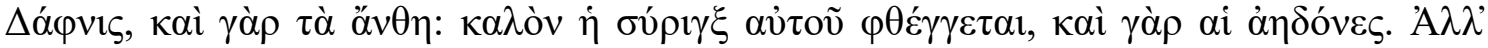

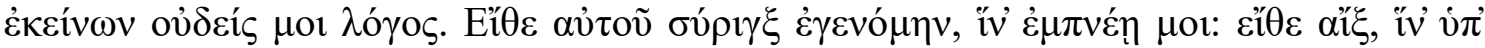

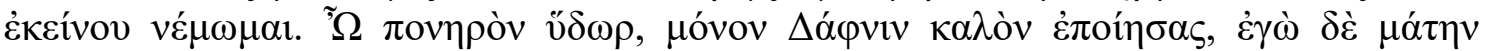

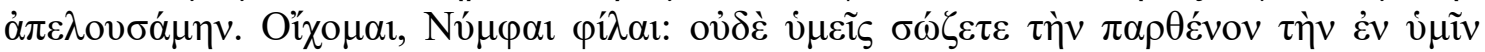

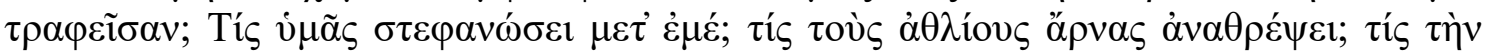

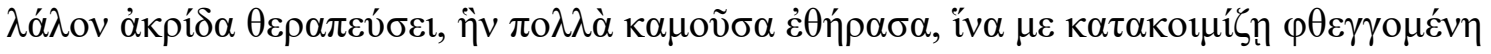

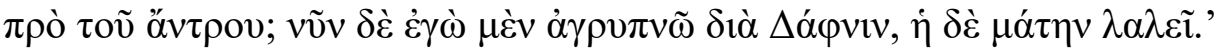

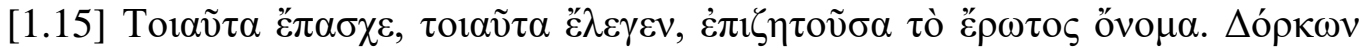

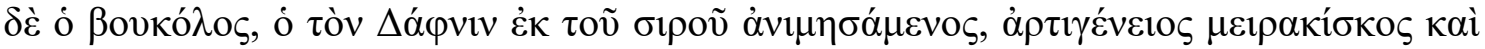

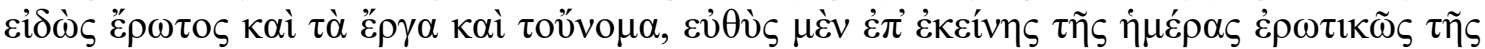

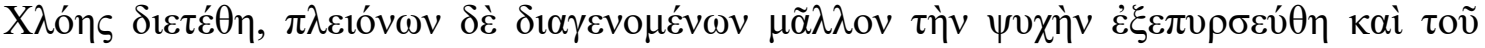

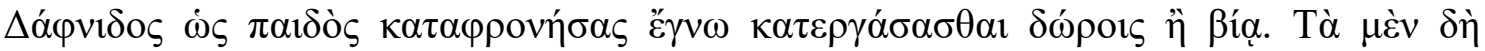

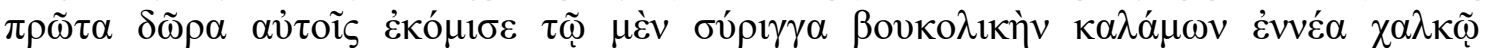

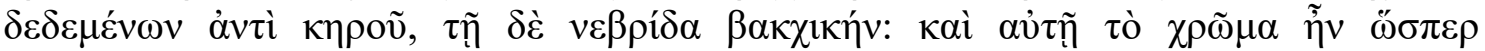

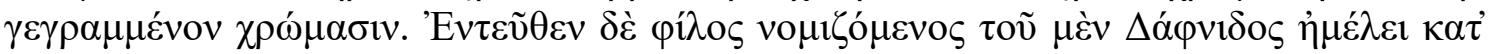

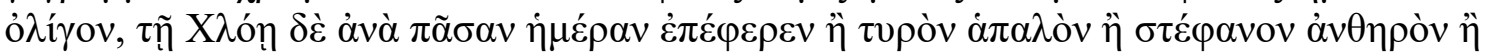

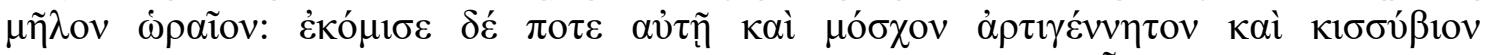

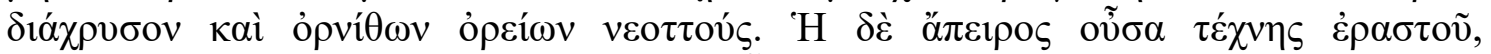

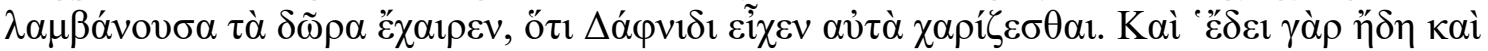

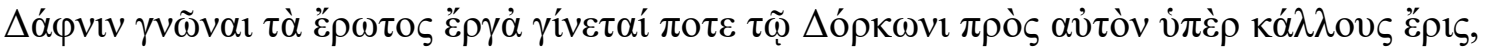

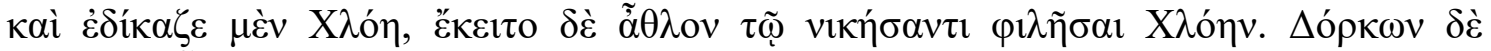
$\pi \rho \cos _{\varepsilon \rho \rho} \tilde{\omega} \delta \varepsilon$ हैं $\varepsilon \gamma \varepsilon v$.

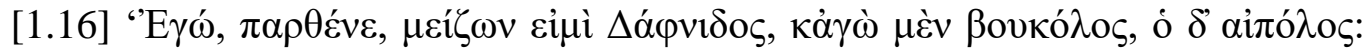

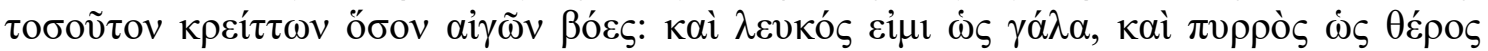

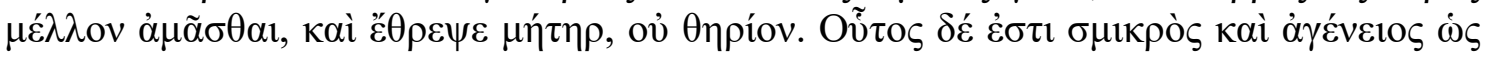

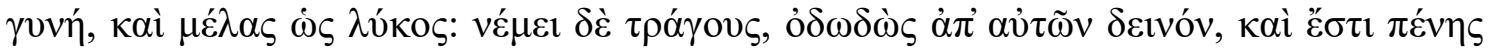

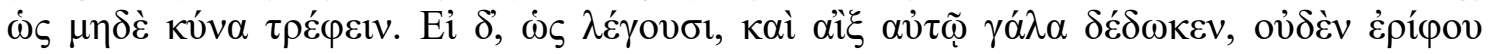

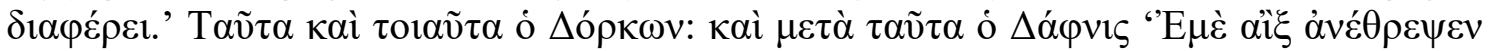

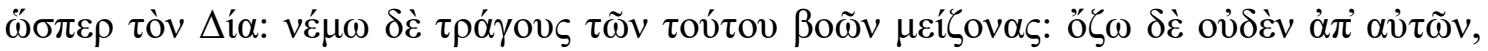

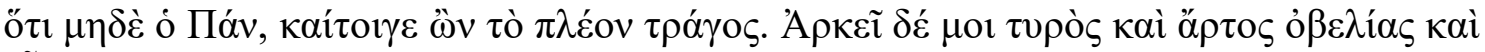

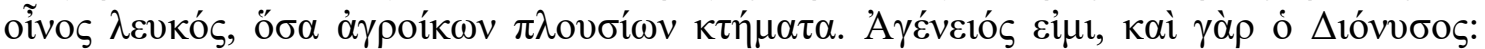

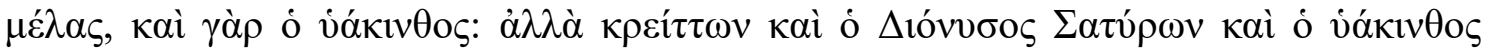

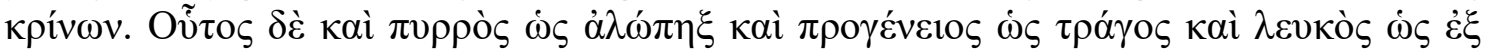

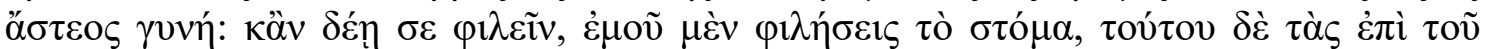

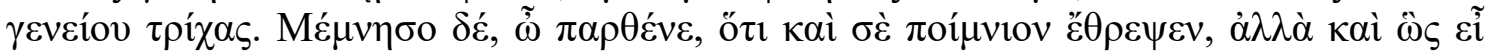

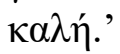

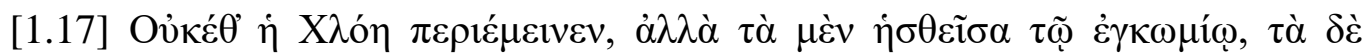

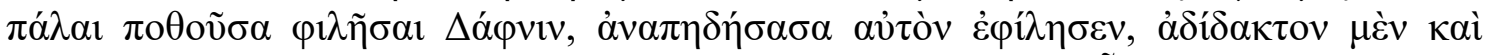

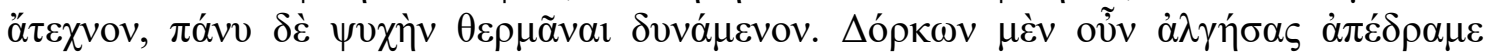

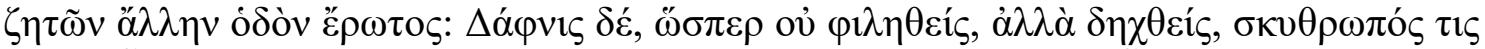

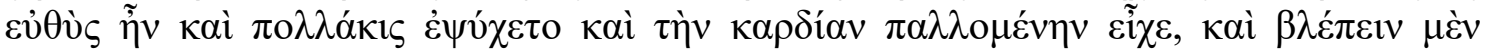

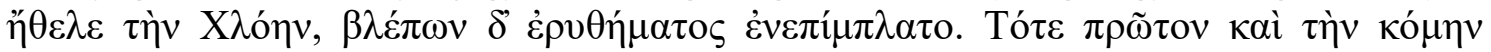

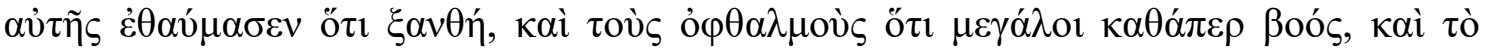

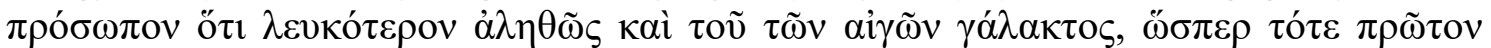

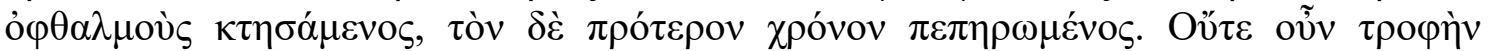

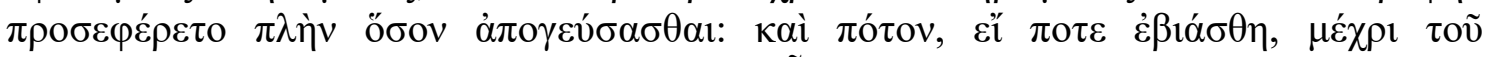

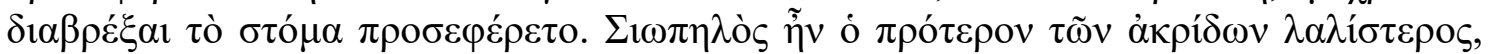

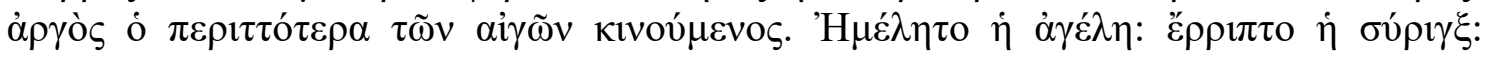




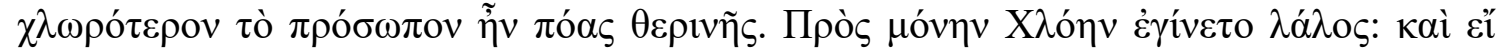

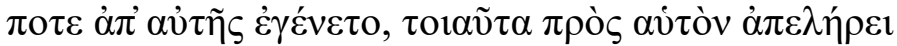

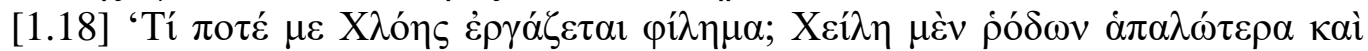

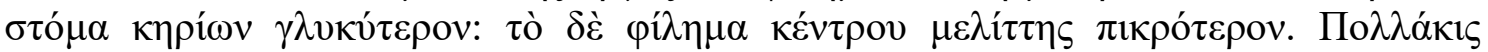

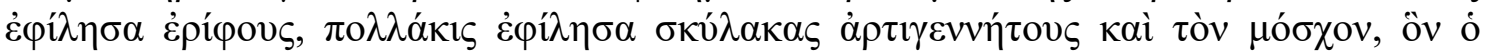

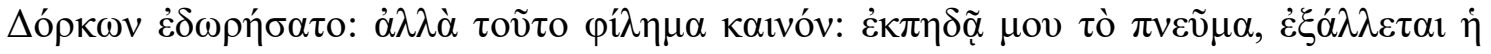

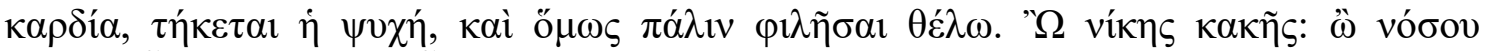

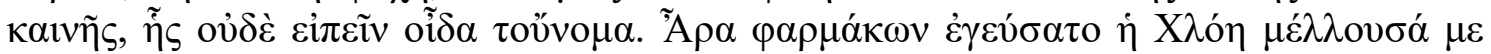

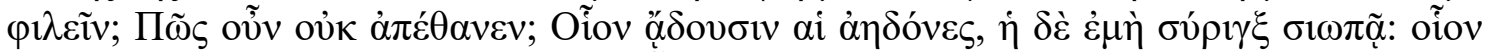

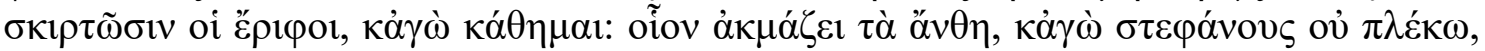

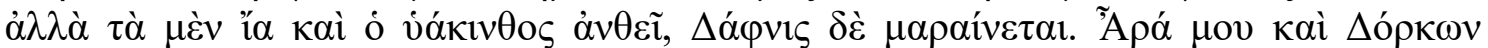

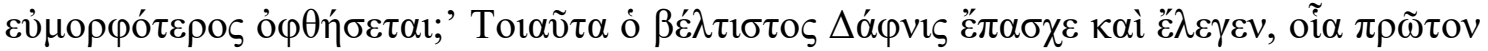

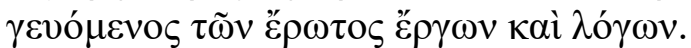

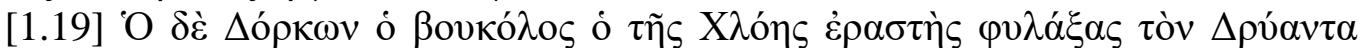

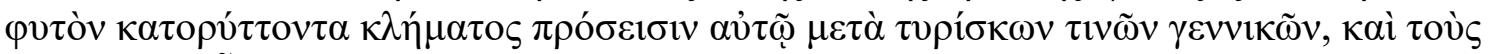

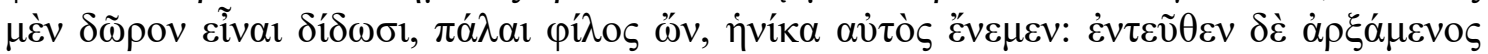

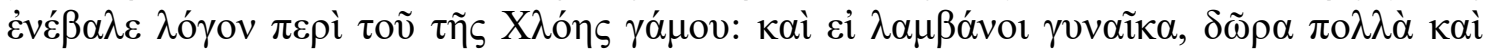

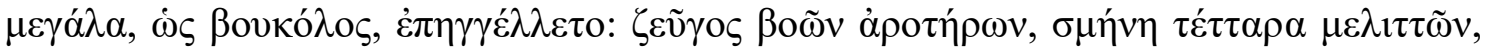

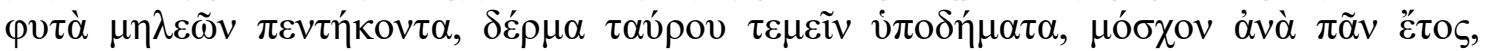

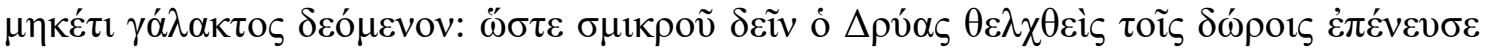

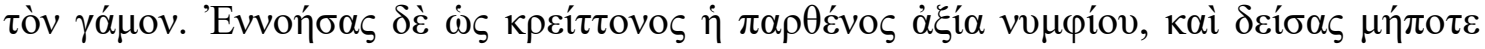

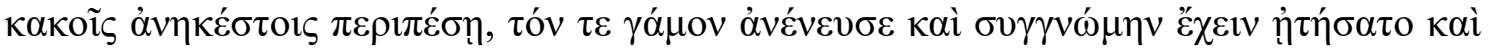
$\tau \alpha \grave{~ o ̉ v o \mu \alpha \sigma \theta \varepsilon ́ v \tau \alpha ~ \delta \tilde{\omega} \rho \alpha \pi \alpha \rho \eta \tau \eta ́ \sigma \alpha \tau o . ~}$

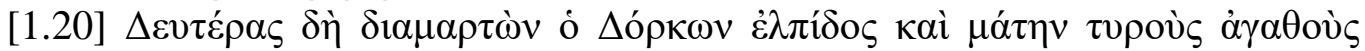

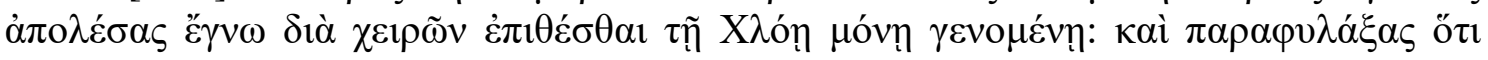

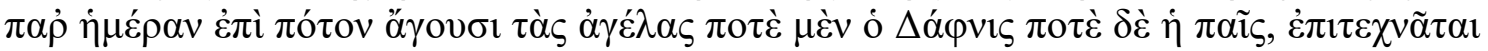

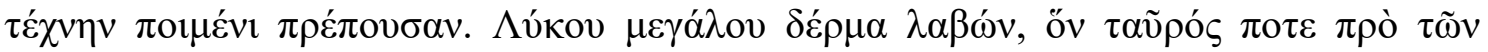

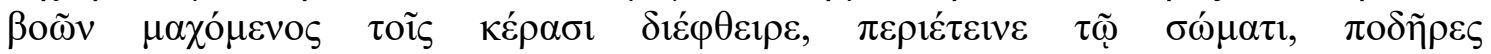

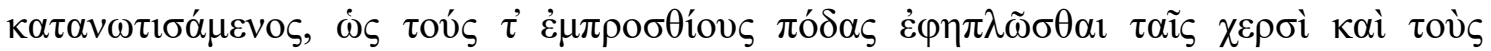

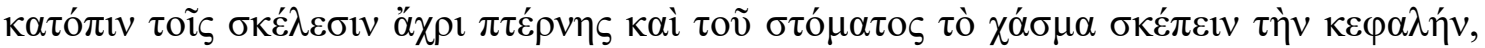

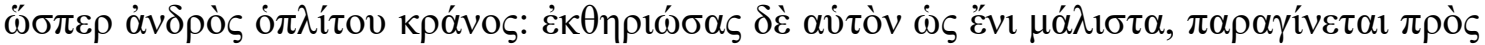

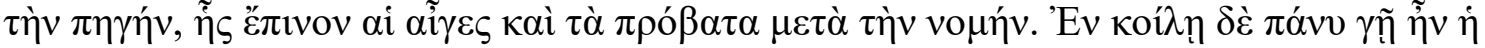

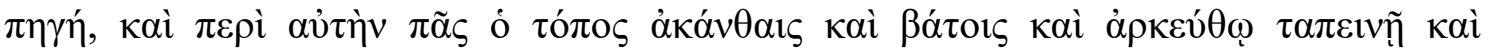

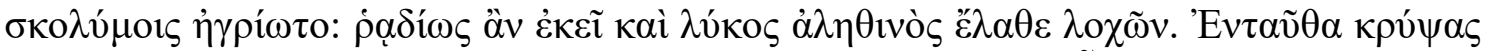

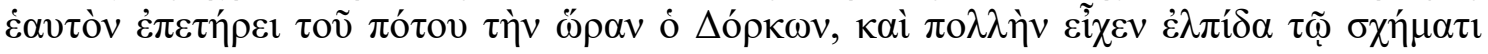

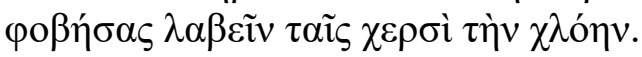

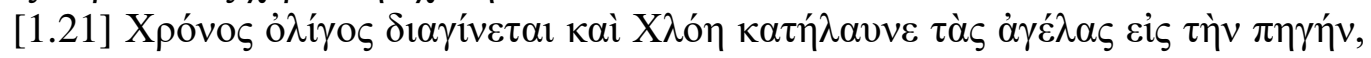

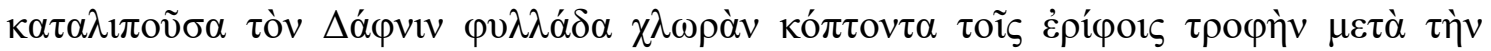

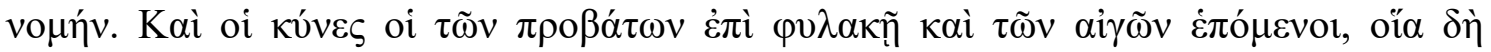

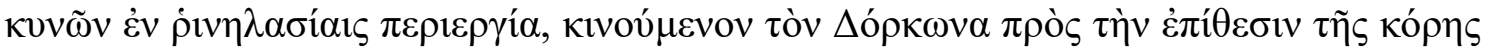

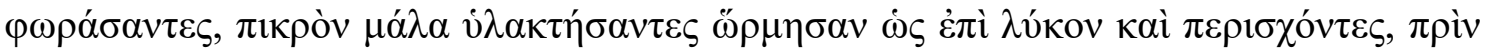

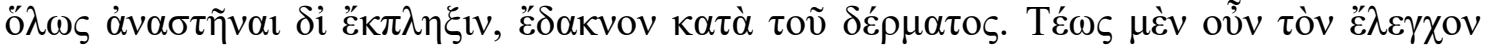

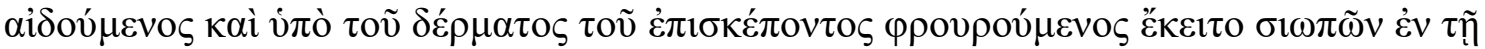

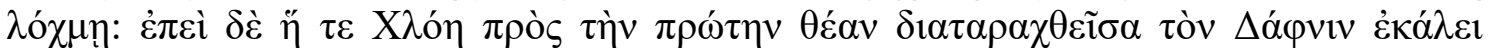

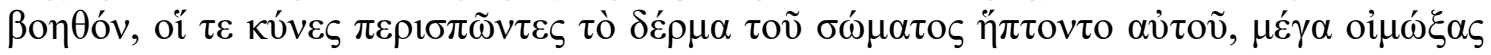

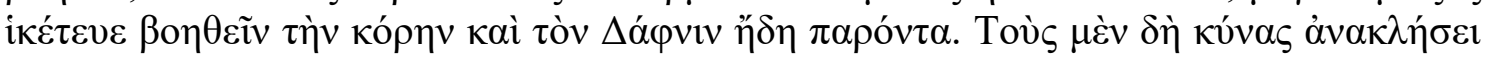

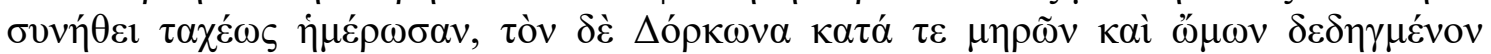

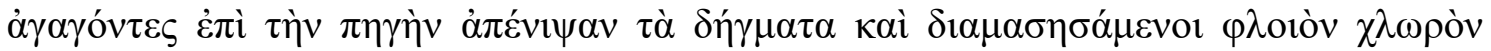

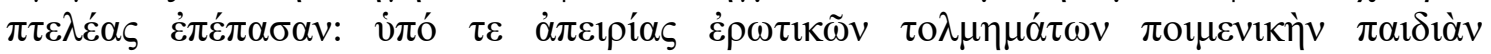




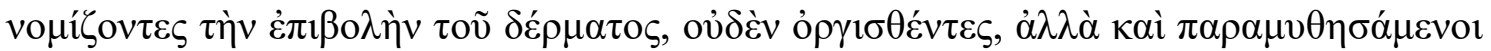

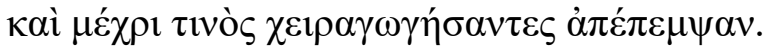

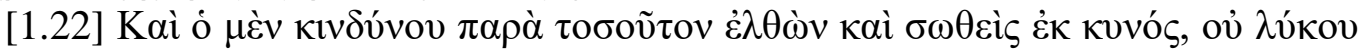

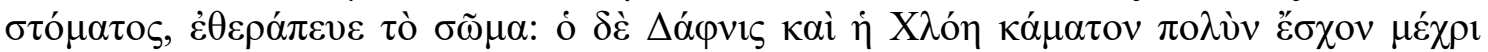

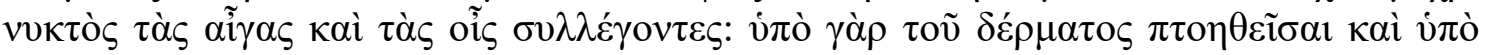

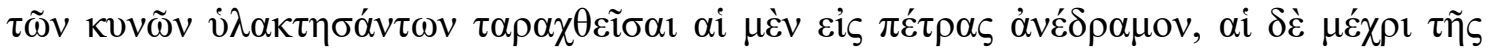

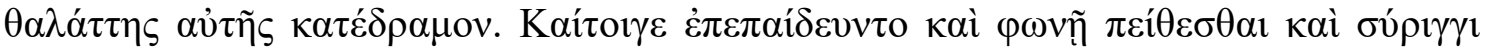

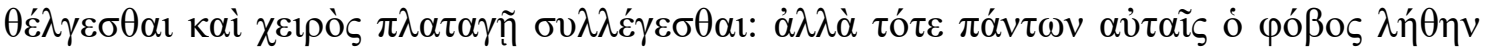

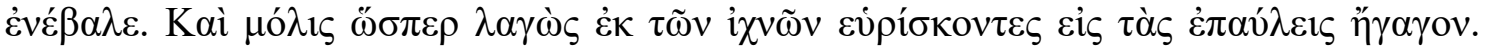

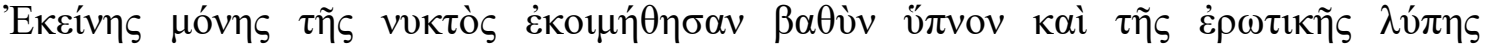

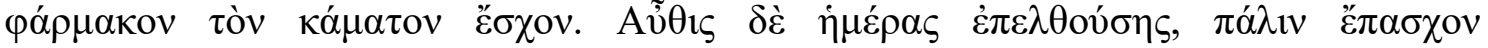

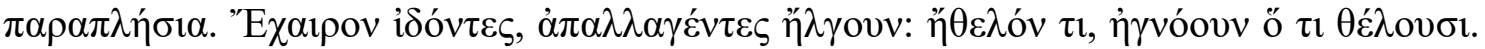

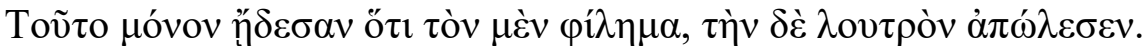

[1.23] 'Е

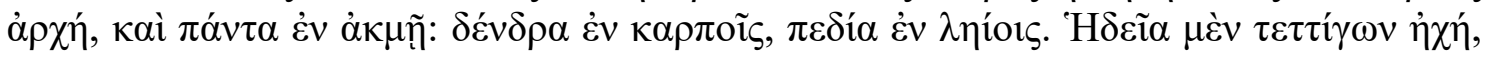

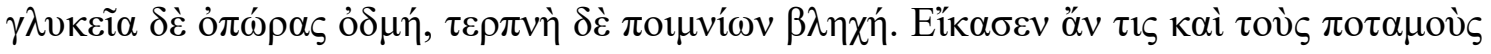

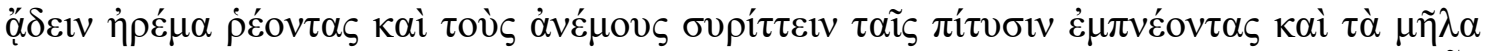

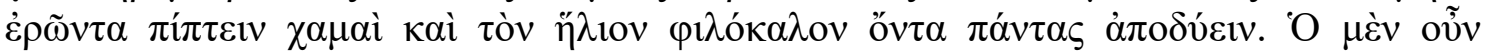

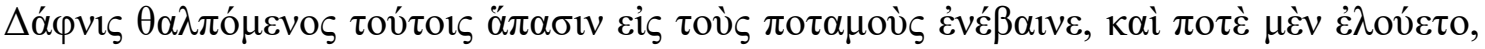

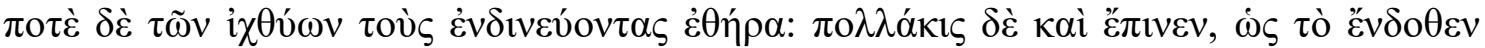

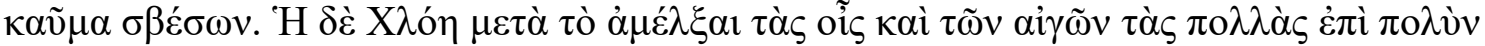

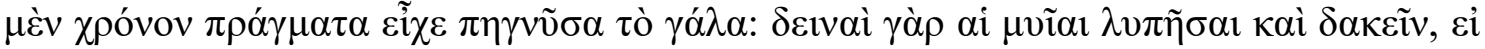

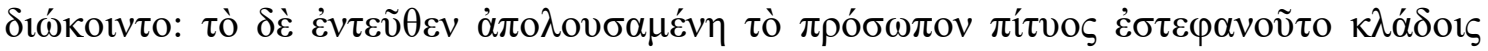

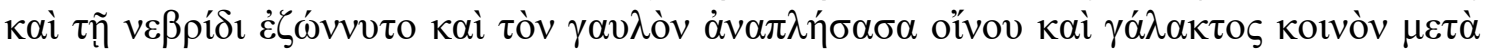

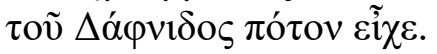

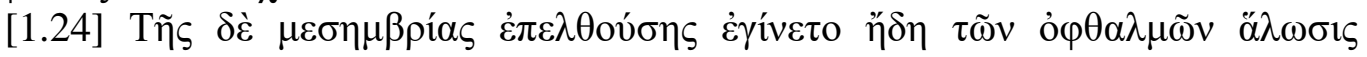

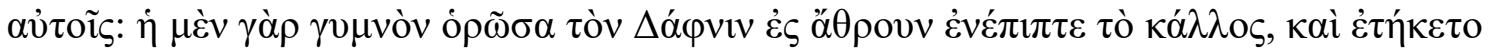

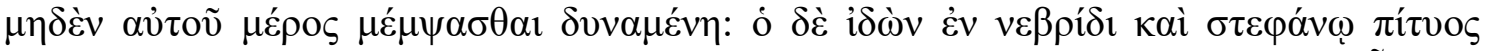

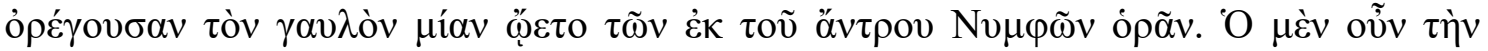

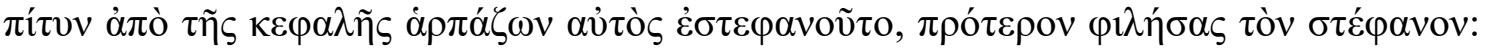

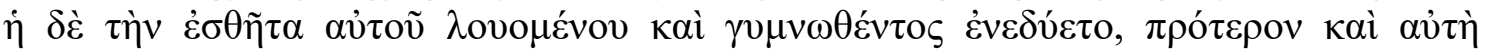

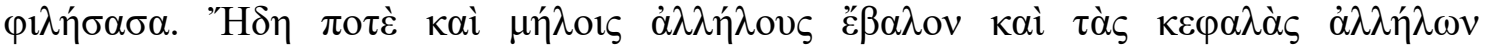

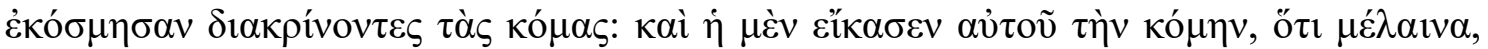

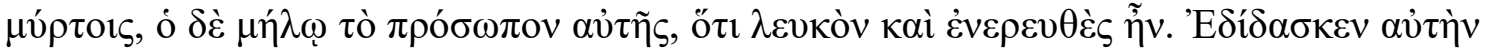

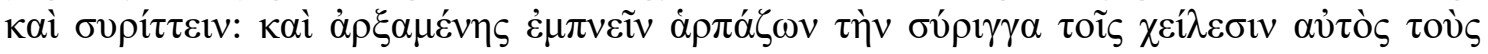

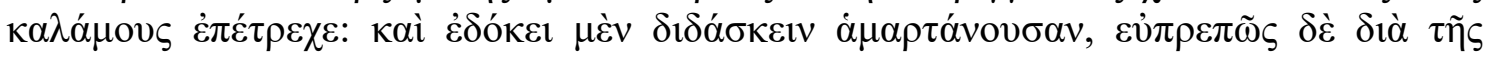

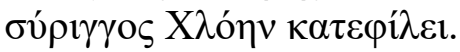

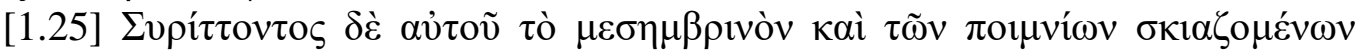

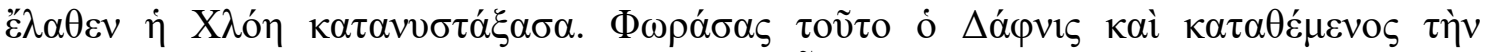

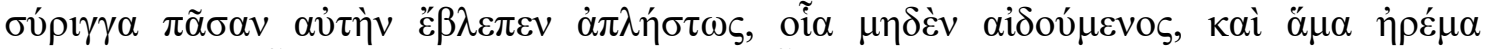

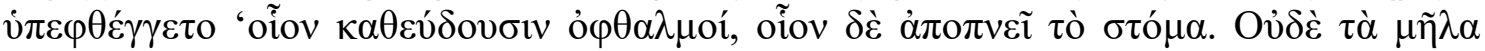

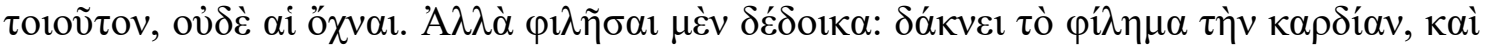

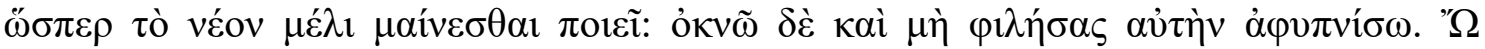

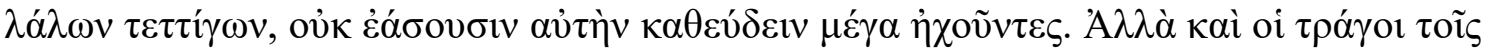

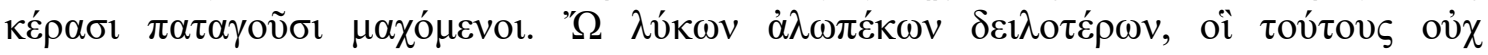

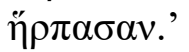

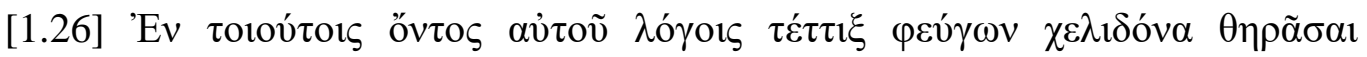

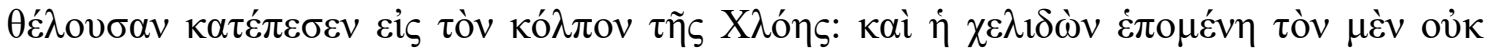

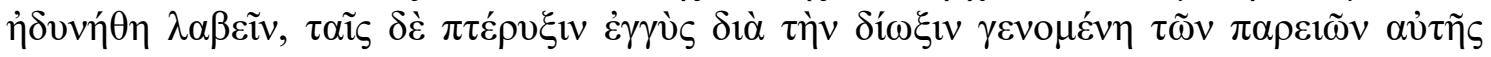




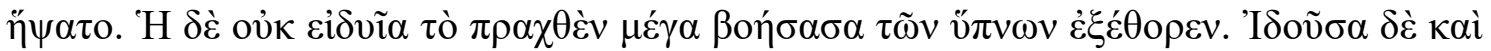

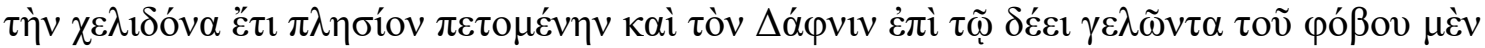

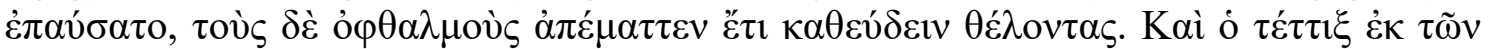

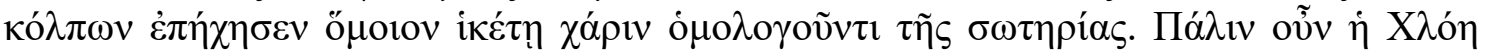

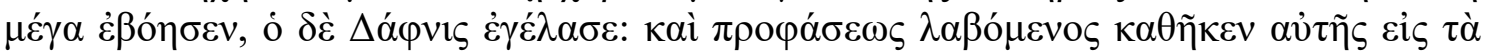

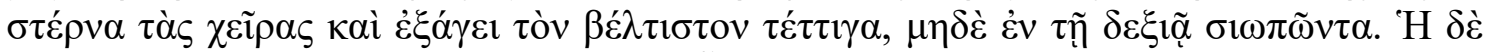

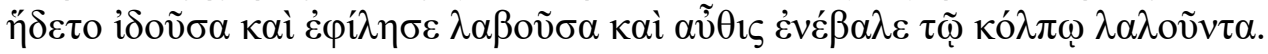

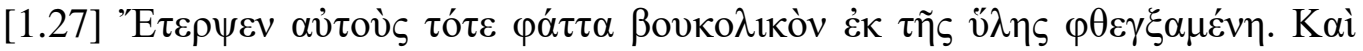

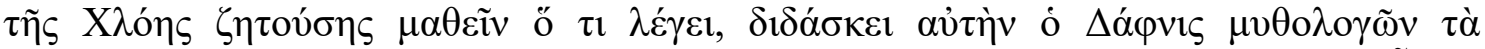

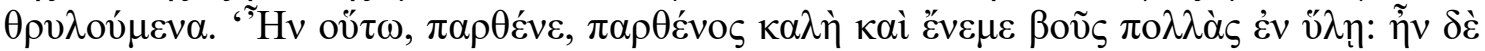

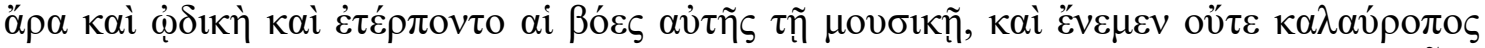

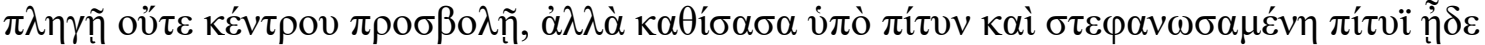

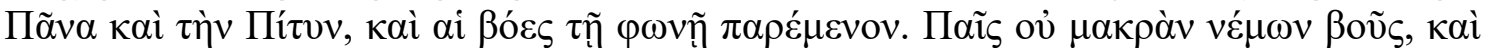

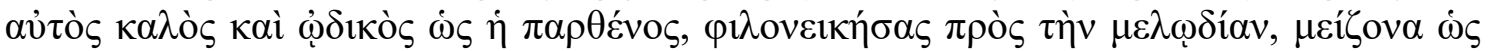

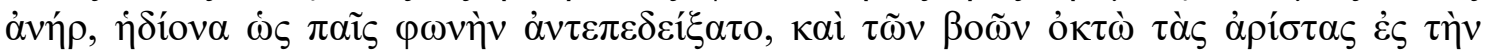

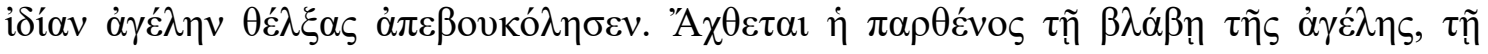

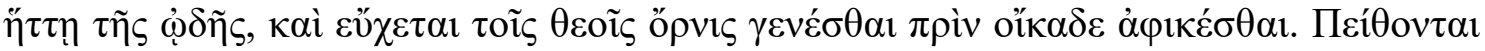

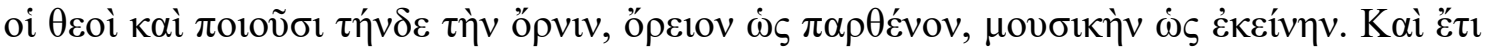

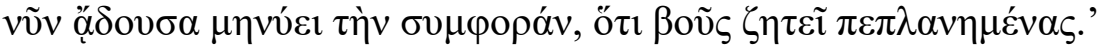

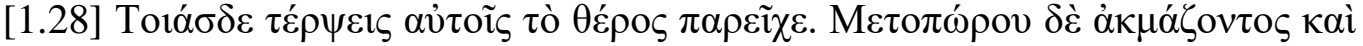

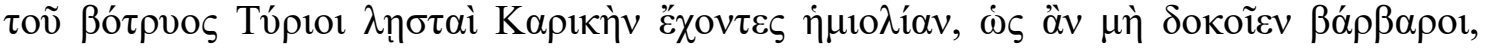

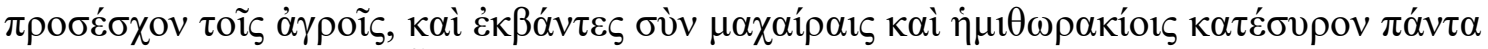

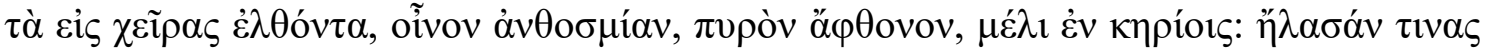

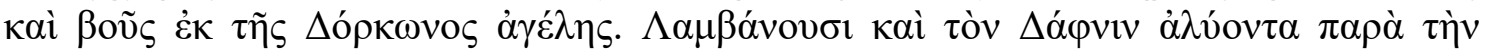

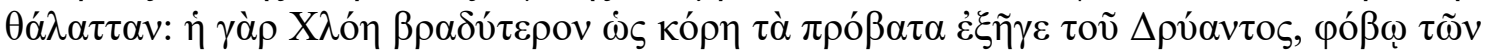

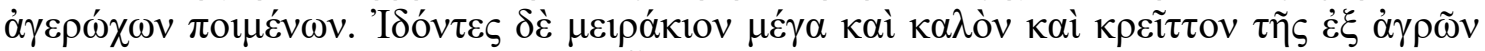

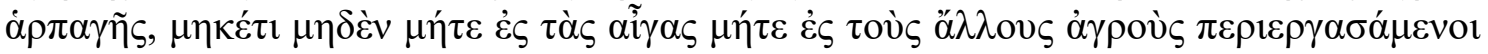

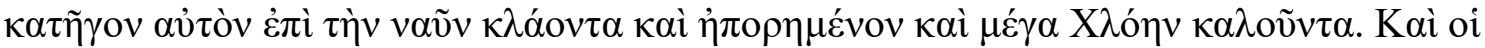

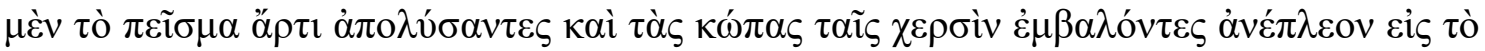

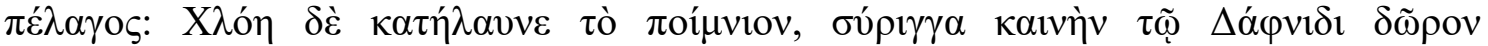

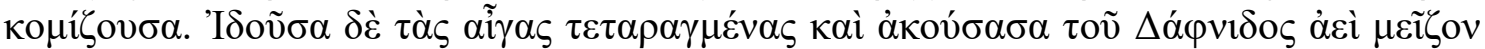
$\alpha$

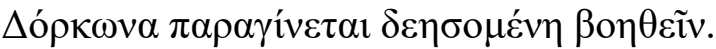

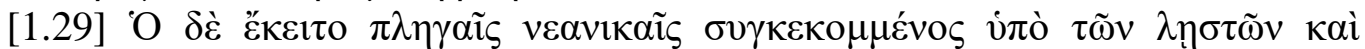

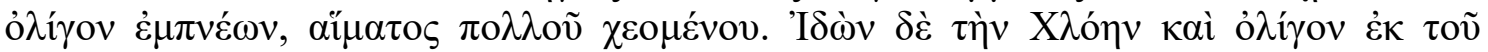

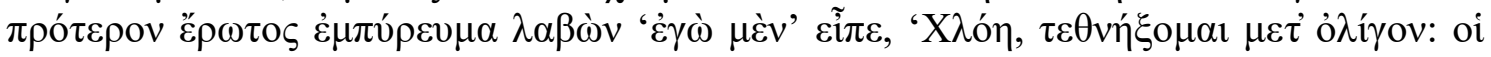

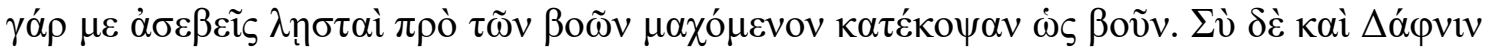

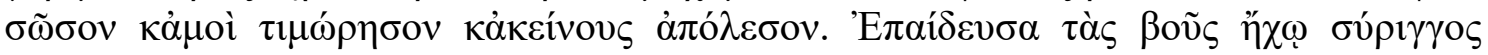

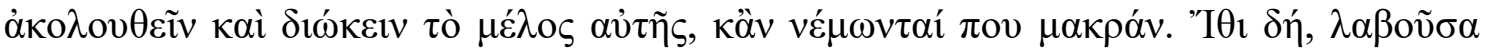

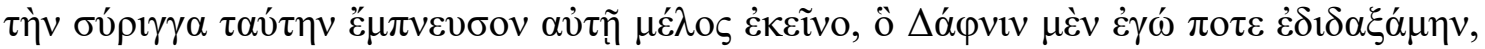

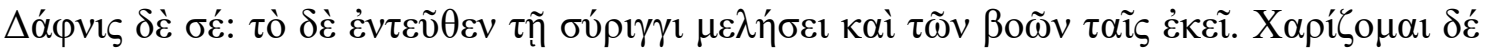

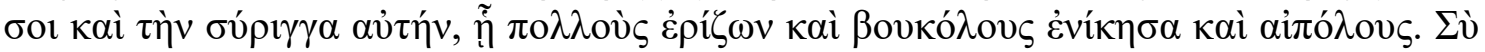

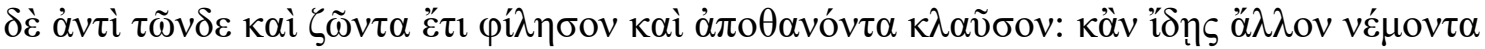

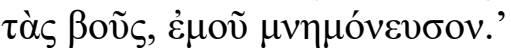

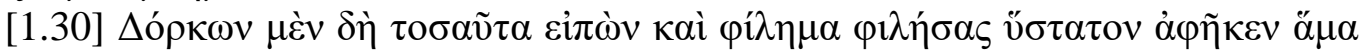

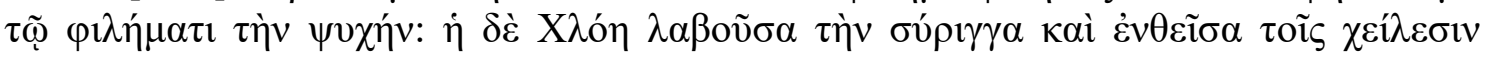

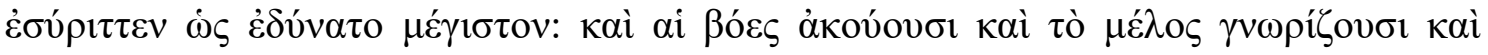

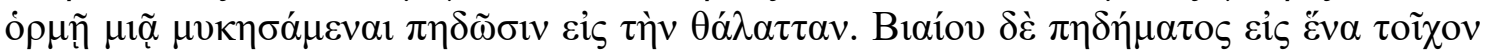

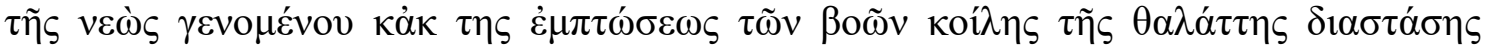




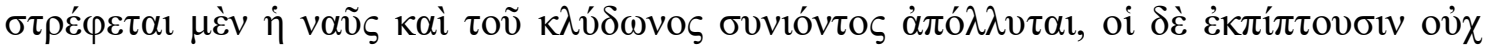

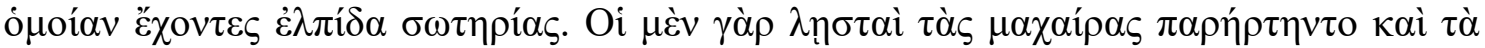

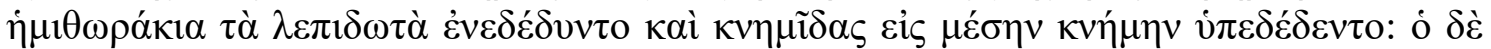

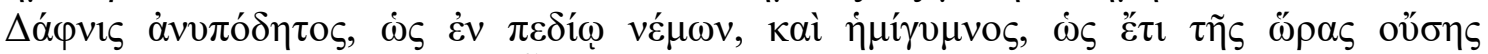

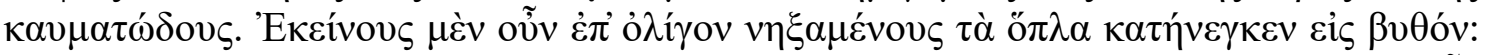

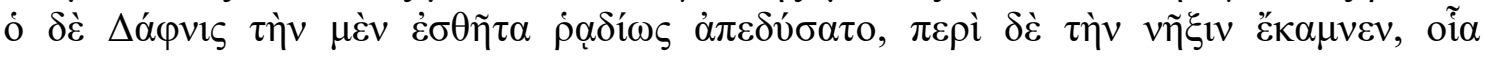

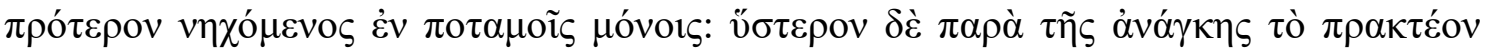

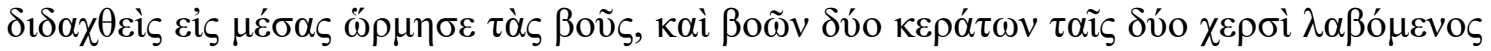

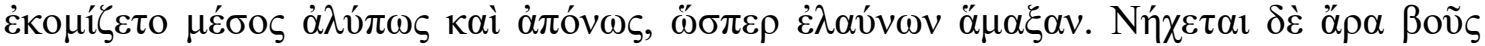

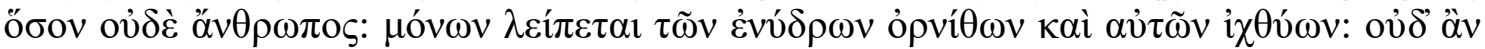

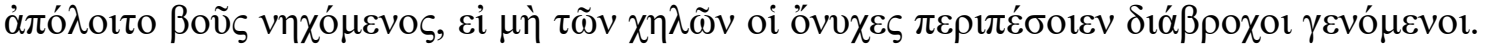

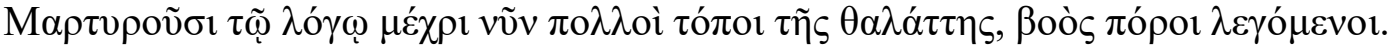

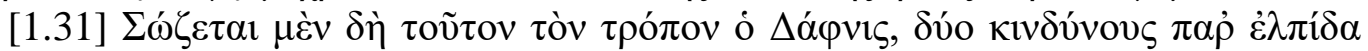

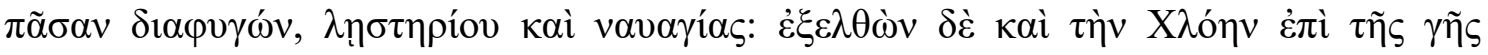

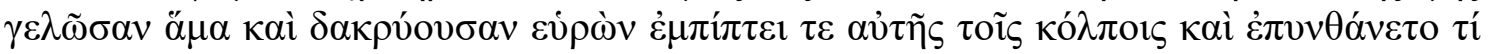

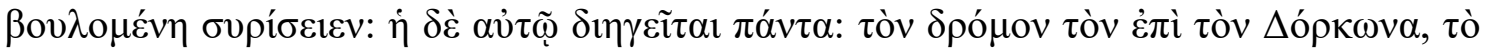

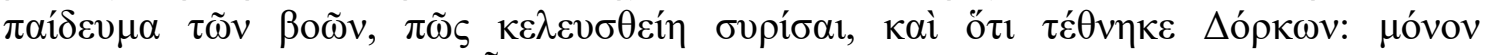

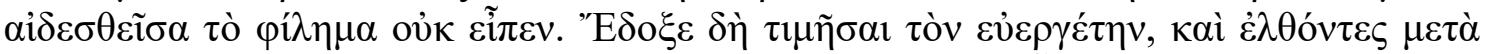

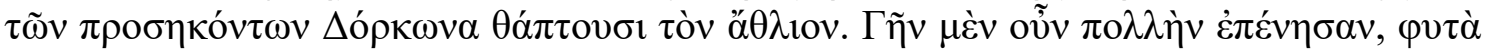

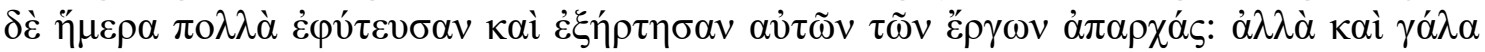

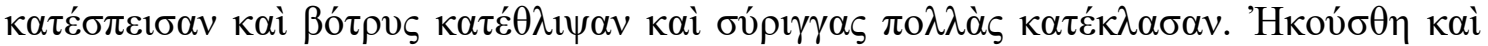

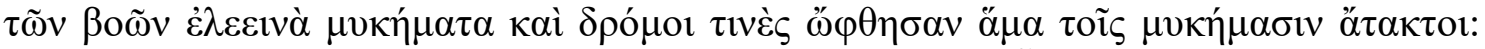

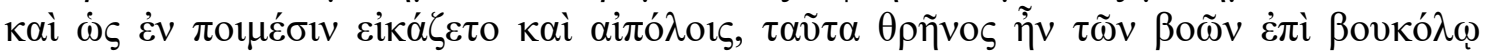

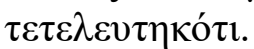

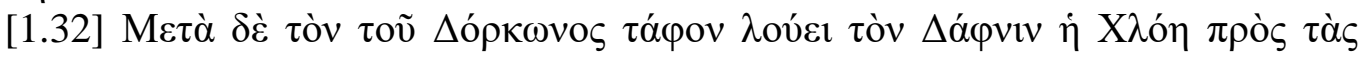

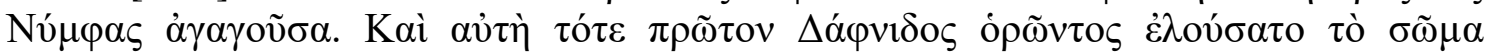

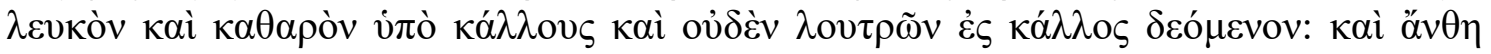

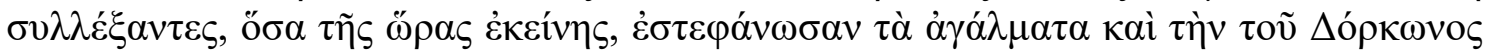

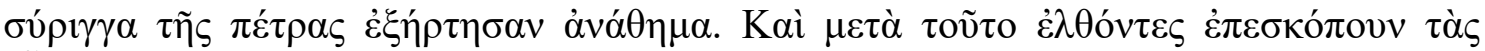

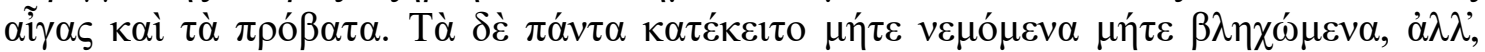

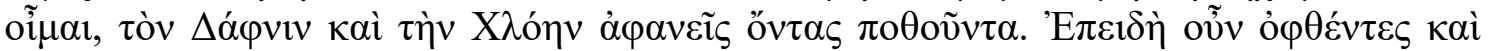

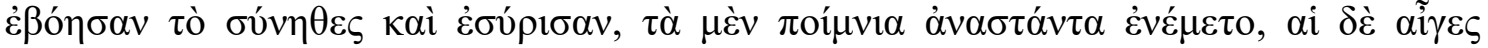

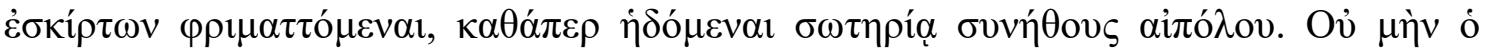

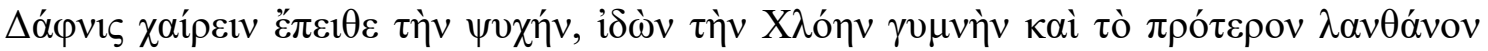

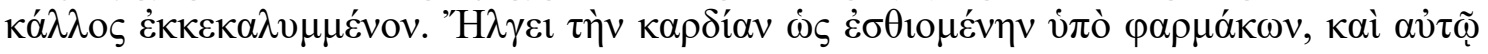

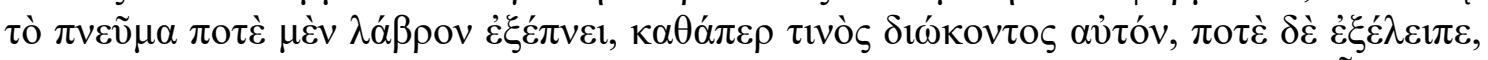

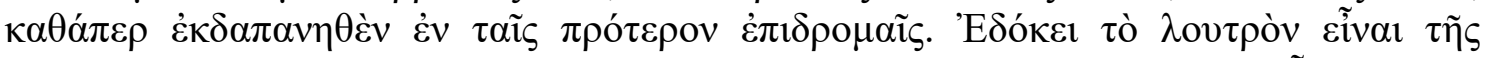

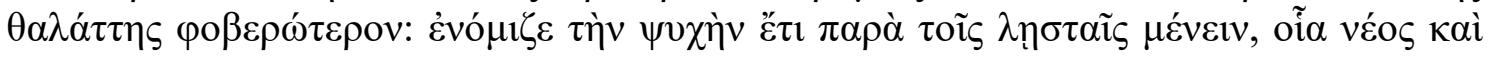

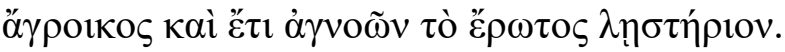

\section{Tradução: Livro Primeiro - Dáfnis e Cloé, de Longo de Lesbos}

\section{Proêmio}

[praef.1] Em Lesbos, quando eu caçava no bosque das Ninfas, contemplei o mais belo espetáculo que jamais contemplei: uma imagem, uma pintura, uma história de amor. Também o bosque era belo, repleto de árvores, de flores, de umidade. Uma só fonte banhava tudo, flores e árvores. A pintura, contudo, era ainda mais encantadora e revelava arte sutil e acaso amoroso - tanto que, por sua fama, muitos, entre eles 
estrangeiros, iam até lá não só para consagrar às Ninfas, mas também para contemplar a imagem. Nela se viam mulheres a parir e outras com cueiros a envolver os rebentos; crianças expostas, ovelhas a amamentá-las; pastores a recolhê-las, jovens inseparáveis; incursão de piratas, ataque de inimigos. Muitas outras cenas, todas amorosas, contemplei e admirei - e um desejo me impeliu a registrá-las pela escrita.

Depois de procurar um intérprete para a imagem, elaborei quatro livros, uma oferenda a Eros, às ninfas e a Pã, uma dádiva encantadora a todos os homens - que curará o doente e animará o pesaroso, que trará lembranças a quem já foi amado, bem como instruirá quem nunca amou. Afinal, ninguém jamais fugiu nem fugirá do amor, enquanto houver beleza e olhos capazes de contemplar. Que o deus nos permita registrar com sensatez os amores alheios!

\section{Livro I}

[1.1] Mitilene é uma cidade de Lesbos, grande e bela. Ela é atravessada por canais por onde o mar circula e adornada com pontes de pedra branca e polida. Você julgaria avistar não uma cidade, mas uma ilha.

A pouco mais de trinta e cinco quilômetros desta cidade, ficava a fazenda de um homem venturado, propriedade belíssima: montanhas a alimentar feras, terras férteis a produzir trigo, colinas com videiras, pastos para os rebanhos. E o mar rebentava suas ondas na orla espraiada, de areia macia.

[1.2] Pastoreando nesta fazenda, um guardador de cabras chamado Lâmon encontrou uma criança mamando sob uma de suas cabras. Havia um bosque de carvalhos, com moita de sarça, hera espalhada e um tapete macio de folhas, sobre o qual jazia a criança. Para este lugar a cabra corria com frequência e às vezes desaparecia; deixando de lado o cabrito, ela passava seu tempo ali junto do bebê. Lâmon, com pena do cabrito abandonado, passa a vigiar as idas e vindas e ao sol do meio dia, seguindolhe o rastro, avista a cabra velando, cautelosa, sobre o bebê, pisando o chão com cuidado para não lhe ferir com as patas, enquanto ele mama o fluxo de leite de seu úbere maternal.

Espantado, naturalmente, ele se aproxima e encontra um bebê menino, grande e belo, envolvido em cueiros bem melhores do que sua sorte de abandonado faria supor. Com o bebê havia ainda um pequeno manto de púrpura, um broche dourado e um punhal com cabo de marfim.

[1.3] Primeiro ele decidiu recolher apenas os objetos de reconhecimento, sem se preocupar com o bebê. Mas depois, com vergonha de não imitar a humanidade de sua cabra, ele monta guarda até a noite e leva tudo para sua esposa Mírtale, tanto os objetos de reconhecimento quanto a criança e a própria cabra. Surpresa com o fato de que cabras pudessem parir crianças, ele explica tudo para ela: como encontrou o bebê exposto, como o vira mamando, como sentiu vergonha por pensar em abandoná-lo para morrer. Por conselho dela, escondem os objetos expostos, passam a considerar a criança como filho próprio e oferecem alimento para a cabra. E a fim de que até seu nome parecesse de pastor, decidem chamá-lo de Dáfnis.

[1.4] Dois anos depois, um pastor que apascentava nos campos vizinhos, de nome Drias, acha-se também ele diante de iguais descobertas e espetáculos. Havia uma gruta de Ninfas, uma rocha enorme, oca por dentro, arredondada por fora. Estátuas das próprias Ninfas tinham sido esculpidas nas pedras: pés descalços, braços desnudos até os ombros, cabelos soltos sobre o pescoço, cintos em torno do quadril, sorriso no semblante. A figura toda representava um grupo de dançarinas. $\mathrm{O}$ espaço da gruta era 
bem no centro da grande rocha. Água brotava de uma fonte, formando uma corrente que se derramava, de modo que um prado bastante plano, com uma relva muita macia, irrigada de umidade, estendia-se diante da gruta. Permaneciam ali cálices e flautas doces depositadas, além de flautas de tubos e varas de pesca, oferendas de velhos pastores.

[1.5] Para este santuário de Ninfas, uma ovelha que parira recentemente se dirigia com frequência, causando muitas vezes a impressão de que tinha se perdido. Querendo puni-la e trazê-la de volta aos bons modos, Drias dobrou um laço de vara verde, qual uma armadilha, e foi até a rocha, com a intenção de agarrá-la. Parado ali, ele nada viu do que esperava, mas apenas uma ovelha que dava muito humanamente seu úbere para intensa sucção de leite, e uma criança que, sem chorar, mudava avidamente de um úbere para outro a boca limpa e luzente, pois a ovelha lambia-lhe a face com a língua, assim que ela se saciava com o alimento. Era uma criança menina e com ela permaneciam também objetos de reconhecimento: um diadema trançado em ouro, sandálias recobertas de ouro e tornozeleiras douradas.

[1.6] Julgando, de fato, o encontro algo divino e aprendendo com a ovelha a ter piedade e a amar a criança, Drias então recolhe o bebê nos braços, guarda os objetos de reconhecimento dentro do alforje e promete às Ninfas, por causa da sorte propícia, alimentar a sua protegida. E como era hora de guardar o rebanho, já de volta do estábulo, ele descreve em detalhe para a mulher as coisas que viu, mostra-lhe os objetos encontrados, exorta-a a acolher a garotinha e a educá-la como se fosse sua, sem revelar nada a ninguém. De fato, Nape (esse era seu nome) tornou-se mãe de imediato e passou a amar a criancinha com tal intensidade, que era como se temesse ser superada pela ovelha. E também ela própria lhe dá, para inspirar confiança, um nome pastoril: Cloé.

[1.7] Essas crianças bem rápido cresceram e a beleza de ambos se revelava superior à da vida rústica. Tinha ele já quinze anos de idade, ela dois a menos, quando Drias e Lâmon tiveram ambos, numa mesma noite, o seguinte sonho. Pareceu-lhes que as Ninfas, aquelas da gruta na qual há uma fonte, na qual Drias encontrou a criança, confiavam Dáfnis e Cloé a uma criança demasiado austera e bela, que possuía asas nos dorsos e portava pequenos dardos, além de um pequenino arco. Atingindo ambos com só um dardo, ela então lhes ordena pastorear - cabras ele, ovelhas ela.

[1.8] Ao contemplar este sonho, os dois ficaram tristes, já que seus filhos se tornariam pastores, a despeito dos cueiros que anunciavam uma sorte melhor. Por esse motivo eles os nutriam com alimentos os mais frugais e lhes ensinavam as letras e tudo quanto havia de mais belo na vida rústica. Contudo, parecia melhor confiar nos deuses, pois os dois tinham sido salvos por providência divina. Depois de comunicar o sonho um ao outro e fazer sacrifícios na gruta das Ninfas à criança com asas (cujo nome não tinham como dizer), eles os enviam como pastores junto com os rebanhos e lhes ensinam cada coisa: como se deve pastorear antes do meio dia, como fazê-lo depois que o calor excessivo abranda; quando levar o rebanho para beber, quando levá-lo para descansar; em quais ocasiões se deve usar o cajado, em quais apenas a voz. Plenos de alegria, eles acolhiam tudo como se fosse uma elevada função e amavam as cabras e as ovelhas muito mais do que os pastores costumavam amar - ela porque atribuía a causa de sua salvação a uma ovelha; ele porque recordava que uma cabra o tinha alimentado quando exposto.

[1.9] Era começo da primavera e todas as flores vicejavam, nos bosques, nos prados e quantas havia nas montanhas. Já se ouvia o zumbido das abelhas, o canto de pássaros maviosos, os saltos dos cordeiros recém-paridos. Ovelhas saltitavam nas montanhas, abelhas zumbiam nos prados, pássaros cantavam nas moitas. Envolvidos pela boa estação, os ternos e jovens pastores imitavam tudo o que ouviam e viam: se 
ouviam o canto dos pássaros, eles começavam a cantar; se viam os cordeiros saltitando, saltavam também com leveza; e imitando as abelhas, colhiam flores que espalhavam umas sobre colo, outras dedicavam às Ninfas, depois de trançar pequenas guirlandas.

[1.10] Pastoreando próximos um do outro, eles tudo faziam juntos. Umas vezes Dáfnis reunia as ovelhas de Cloé que se desgarravam; outras vezes, era Cloé quem reconduzia as cabras mais arredias de Dáfnis de junto da beira do riacho; outras vezes ainda apenas um guardava ambos os rebanhos, enquanto o outro se distraía com brincadeiras. Eles conheciam infantis brincadeiras de pastores. Ela colhia talos de asfódelos de um campo qualquer, trançava com eles armadilhas para gafanhotos e, envolvida nisso, descuidava das ovelhas. Ele cortava caniços macios, perfurava um a um os intervalos entre os nós e, unindo-os com cera derretida, praticava com sua nova flauta até anoitecer. Às vezes, dividiam o leite e vinho, e dos alimentos que traziam de casa faziam repasto comum. Mais fácil seria ver as ovelhas e as cabras afastadas umas das outras do que Cloé e Dáfnis.

[1.11] Dessa maneira eles folgavam, mas Eros lhes preparou a seguinte provação.

Uma loba, que criava seus filhotes naquela região, numerosas vezes capturou dos campos vizinhos presas de outros rebanhos, por carecer de demasiado alimento para o sustento dos filhotes. Reunidos, os aldeões cavam então covas durante a noite, com a largura de uma braça e a profundidade de quatro. A maior parte da terra revolvida transportam e depositam ao longe e, estendendo longas varas secas sobre o buraco, espalham o resto por cima, imitando a terra anterior - de tal modo que, mesmo se uma lebre corresse sobre ela, quebraria as varas, que eram mais fracas que palha, só então descobrindo tratar-se, não de terra firme, mas de imitação de terra firme. Embora tivessem cavado muitos fossos assim, tanto nas montanhas quanto nas planícies, não lograram capturar a loba, pois ela pressentia o chão preparado. Além disso, tais covas fizeram perecer muitas cabras e cordeiros, e por pouco Dáfnis, como se saberá.

[1.12] Dois bodes irados começaram uma luta. Com uma pancada mais violenta, o chifre de um foi quebrado pelo outro que, com dor e resfolegando, lançou-se em fuga. E o vencedor, seguindo-lhe o rastro, sem cessar lhe instigava a fuga. Dáfnis se compadeceu do chifre e da audácia e, irritado, pegou o cajado e perseguiu o perseguidor. E tanto o perseguido quanto o perseguidor, com cólera, não veem o que está à frente e num buraco ambos caem, o bode primeiro, Dáfnis em segundo.

Eis o que salvou Dáfnis: ter sido amparado pelo bode em sua queda. Chorando ele esperava quem lhe tirasse dali, se é que alguém viria. Cloé, que tinha visto o ocorrido, vai correndo até a cova para acudir e, ao saber que ele está vivo, corre a chamar um vaqueiro dos campos próximos para ajudar. Ele veio, procurou por uma corda grande, capaz de tirá-los dali. Mas como não havia corda, Cloé solta a faixa de seu peito e entrega-a ao vaqueiro para que a lance. Firmes na beirada do fosso, eles começaram a puxar, enquanto Dáfnis subia acompanhando com as mãos os puxões da faixa. Içaram também o bode infeliz que ambos os cornos quebrou, de modo que a justiça passou para o lado do bode vencido. Os dois o oferecem como recompensa ao vaqueiro para ser sacrificado e decidem mentir aos de casa, dizendo, caso alguém desse pela falta dele, que fora atacado por lobos.

De volta, eles próprios percorreram os rebanhos de ovelhas e de cabras. E uma vez que notaram tanto cabras quanto ovelhas em ordem no pasto, sentaram-se ao pé de um tronco de carvalho e examinaram se em alguma parte do corpo de Dáfnis, com a queda, havia sangramento. Nem ferida, nem sangramento havia; ele apenas estava 
coberto de terra e de lama, tanto nos cabelos quanto no resto do corpo. Precisava de fato era banhar-se, antes que Lâmon e Mírtale percebessem o ocorrido.

[1.13] E indo com Cloé à gruta das Ninfas, deu a ela sua túnica curta e seu alforje, para que os guardasse. Ele se aproximou da fonte e lavou a sua cabeleira, assim como todo o corpo. Sua cabeleira era negra e vasta, e a pele tisnada de sol - alguém poderia supor que ela fora tingida pela escuridão da cabeleira. A Cloé, que o contemplava, ele pareceu belo. E como ele, pela primeira vez, lhe parecesse belo, julgou ser o banho a causa da beleza. Quando esfregava seu dorso, a carne se mostrava tão delicada que ela, com discrição, tocava em si mesma com frequência, na tentativa de saber se ela seria mais tenra. E como o sol já se punha, tangeram por fim os rebanhos para casa - e Cloé não sentia outra coisa, senão o desejo de contemplar Dáfnis a se banhar de novo.

No dia seguinte, quando foram para o pasto, Dáfnis sentou-se sob o carvalho de costume e tocou sua flauta, enquanto vigiava as cabras que, deitadas, pareciam prestar atenção às suas músicas. Cloé, por sua vez, perto sentada, contemplava seu rebanho de ovelhas, mas na maior parte do tempo olhava mesmo era para Dáfnis. Tocando flauta, ele lhe parecia de novo belo e mais uma vez ela acreditou que a música era a causa da beleza - tanto que, depois dele, também ela própria pegou da flauta, a ver se também se tornaria bela. Convenceu-o depois a se banhar novamente e o viu no banho e, vendo-o, tocou-o e de novo voltou para a casa admirada - e a admiração era o princípio do amor.

O que então a jovem menina experimentava, ela não sabia - ela que fora criada no campo e jamais ouvira mencionar o nome do amor. Um torpor dominava sua alma e ela já não controlava os olhos e murmurava o nome de Dáfnis a todo instante. Descuidava do alimento, atravessava a noite insone, desdenhava do rebanho. Ora ria, ora chorava. A seguir adormecia, depois, de um salto, despertava. $\mathrm{O}$ rosto empalidecia, logo ardia em brasa. Nem vaca espetada por aguilhão faz coisas assim. Quando estava sozinha, às vezes lhe vinham estas palavras:

[1.14] - Eu agora estou doente, mas que doença é essa ignoro. Sinto dor e não tenho qualquer ferida. Estou aflita e não perdi nenhuma ovelha. Ardo e estou sentada sob esta sombra. Quantos espinhos já me feriram, sem que eu chorasse! Quantas abelhas já me ferroaram, mas eu me alimentei! O que fere meu coração é mais doloroso do que tudo isso. Dáfnis é belo, e também as flores. A sua flauta sibila belamente, e também as andorinhas. Mas estes não me dizem nada. Ah se eu fosse sua flauta, para que ele me soprasse! Ah se eu fosse uma cabra, para ser guardada por ele! Oh água miserável, só Dáfnis você tornou belo! Eu me banhei e foi em vão. Estou perdida, Ninfas queridas! Nem vocês podem salvar a donzela que criaram? Quem coroará vocês com guirlandas, depois de mim? Quem alimentará os pobres cordeiros? Quem cuidará da cigarra canora, que me esforcei para caçar, a fim de que embalasse meu sono cantando diante da gruta? Agora já não durmo, por causa de Dáfnis, e ela canta em vão.

[1.15] Eis o que ela sofria, eis o que ela dizia, tentando descobrir o nome do amor.

Dórcon, o vaqueiro que tinha içado Dáfnis da cova, rapazinho de barba recente e que conhecia o amor, seus trabalhos e seu nome, foi tomado já naquele dia de uma súbita paixão por Cloé. Quanto mais os dias passavam, mais ele ardia em sua alma. E com desprezo por Dáfnis, por ser um garoto, sabia como alcançar seu objetivo, fosse com presentes, fosse pela força. Assim, ofereceu para eles os primeiros presentes: para ele, uma flauta pastoril com nove caniços, unidos com bronze em lugar de cera; para ela, uma pele de corça, qual de uma bacante, cujo colorido era tal que parecia pintado com muitos tons. A partir daí, considerado como amigo, ele passou pouco a pouco a 
ignorar Dáfnis - mas para Cloé, a cada dia, oferecia ou um queijo macio ou uma guirlanda de flores ou uma maçã madura. Certa vez levou-lhe um novilho parido recentemente e um cálice com detalhes dourados, além de filhotes de passarinhos montanheses. Ela, inexperiente na arte do cortejo, alegrava-se ao receber os presentes, pois com eles procurava agradar Dáfnis.

E como já era preciso que também Dáfnis conhecesse os trabalhos do amor, eis que certo dia ocorre uma disputa de beleza entre Dórcon e ele, com Cloé como juíza. Instituiu-se como prêmio ao vencedor um beijo de Cloé. Dórcon, em primeiro lugar, falou deste modo:

[1.16] - Eu, donzela, sou mais alto que Dáfnis. Sou vaqueiro, ele pastor de cabras. Eu o supero tanto quanto bois superam cabras. Também sou alvo como leite e ruivo como messe prestes a ser colhida e minha mãe foi quem me nutriu, não um animal. Ele é baixo e imberbe como uma mulher e moreno como um lobo. Pastoreia bodes e exala o terrível cheiro deles e é tão pobre que nem um cão é capaz de sustentar. Se, como dizem, uma cabra o amamentou, ele em nada difere de um cabrito.

Estas as palavras de Dórcon, a que seguiram as de Dáfnis:

- A mim me nutriu uma cabra, tal como a Zeus. Pastoreio bodes bem maiores do que os bois dele, mas não exalo seu odor, do mesmo modo que Pã não exala odor algum, embora seja bode em grande parte do corpo. Para mim são suficientes queijo e pão de rolo e vinho branco tanto quanto os bens aos fazendeiros ricos. Sou imberbe, assim como Dioniso; moreno, assim como o jacinto. Mas Dioniso também supera os Sátiros e o jacinto, os lírios. Ele é ruivo como uma raposa e barbudo como um bode e branco como uma mulher da cidade. Se eu puder beijar você, beijará a minha boca, não os pelos de uma barba. Lembre-se, donzela, também uma ovelha a nutriu, mas mesmo assim você é bela.

[1.17] Cloé não esperou mais nada - alegre com o elogio e desejosa, desde antes, de beijar Dáfnis, de um salto beijou-o, sem habilidade e sem arte, mas bem capaz de incendiar-lhe a alma. Dórcon, então, sofrendo, saiu correndo, já pensando em outro caminho até o amor. E Dáfnis, como se tivesse sido não beijado, mas mordido, ficou carrancudo de imediato e passou a tremer com frequência e a sentir o coração disparado. Queria olhar para Cloé, mas se a via ficava ruborizado. Então, pela primeira vez também, admirou a cabeleira dela, que era loira, e os olhos, que eram grandes como os de uma vaca, e o rosto, que era em verdade mais alvo que o leite das cabras - como se pela primeira vez tivesse olhos e todo o tempo anterior estivesse privado da visão. Ele agora já não punha alimento na boca, senão para provar. E água, se às vezes era forçado a beber, levava-a à boca apenas para umedecê-la. Permanecia calado, ele que era mais falante que as cigarras; parado, ele que era mais lépido do que as cabras. O rebanho estava esquecido; a flauta abandonada; e o seu rosto mais pálido do que as ervas durante o verão. Só falava com Cloé. E se às vezes se afastava dela, dizia para si mesmo coisas sem sentido assim:

[1.18] - O que o beijo de Cloé está fazendo comigo? Os lábios dela são mais macios que as rosas e a boca mais doce que o mel - mas o beijo mais ardido do que ferrão de abelha. Algumas vezes beijei cabritos, outras vezes beijei filhotes recémnascidos de cadelas e até o novilho que Dórcon nos ofertou. Mas esse beijo é estranho: a respiração me falta, meu coração dispara, minha alma derrete - e, no entanto, quero beijá-la de novo! Que vitória perversa! Que doença estranha, da qual nem sequer sei o nome! Acaso Cloé provou de algum veneno, antes de me beijar? Como então ela não morreu? Como cantam as andorinhas - e minha flauta está calada! Como saltitam os cabritos - e eu aqui parado! Como vicejam as flores - e eu sem trançar guirlanda 
alguma! As violetas e o jacinto florescem, só Dáfnis definha. Será que Dórcon é mais formoso do que eu?

Eis o que sofria e dizia o excelente Dáfnis, ao experimentar, pela primeira vez, os trabalhos e os temas do amor.

[1.19] Dórcon, o vaqueiro, o enamorado de Cloé, tendo visto Drias plantando um pé de videira, aproxima-se dele com uns queijinhos de boa qualidade e os oferece como presente, por ser dele um amigo antigo, desde o tempo em que ele próprio guardava seus rebanhos. Começou daí e introduziu o assunto do casamento com Cloé. Que se ele a desse como esposa, muitos presentes valiosos ele, como vaqueiro, lhe ofertaria: uma parelha de bois de lavra, quatro colmeias de abelhas, cinquenta pés de macieira, pele de touro para o fabrico de sandálias, um novilho por ano, tão logo desmamasse. Assim Drias, encantado com os presentes, por pouco não concordou com o casamento. Refletindo, porém, que a donzela era digna de um noivo melhor e temendo cair em males irreparáveis, negou-lhe o casamento, pediu desculpas e recusou os presentes mencionados.

[1.20] Dórcon, frustrado em sua esperança pela segunda vez e tendo perdido em vão excelentes queijos, considerou pegar Cloé à força quando estivesse sozinha. Como todos os dias ora Dáfnis ora a garota conduziam os rebanhos até a água, ele inventa um artifício adequado a um pastor e se põe de guarda. Pegando a pele de um grande lobo, que um touro certa vez, em defesa dos bois, combateu e matou com seus cornos, envolveu o corpo, cobrindo-o dos ombros aos pés, de modo que as patas dianteiras se estendiam sobre seus braços e as traseiras sobre as pernas até os calcanhares, enquanto a abertura da boca abrigava sua cabeça, tal qual o capacete de um hoplita. Tornando-se selvagem o mais possível, ele se acerca da fonte, aonde as cabras e as ovelhas vinham beber depois que pastavam. A fonte ficava num vale muito escarpado e todo o lugar em volta dela era selvagem, repleto de espinheiros e sarças e zimbro e cardos. Um lobo de verdade dificilmente seria visto, se ficasse de tocaia ali. Deste lugar, escondido, Dórcon vigiava a hora de os rebanhos beberem e tinha grande esperança de assustar Cloé com sua aparência e colocar as mãos em cima dela.

[1.21] Pouco tempo se passou e Cloé tangeu os rebanhos até a fonte, deixando para trás Dáfnis, que cortava folhas verdes para alimentar os cabritos depois do pastoreio. E os cães, escoltando atentos ovelhas e cabras, por causa da curiosidade própria de seu faro canino, flagraram os movimentos de Dórcon prestes a atacar a garota e começaram a latir com muita ferocidade, como se para um lobo. E, encurralando-o, sem que ele por causa do medo pudesse se levantar, morderam a pele de lobo. Até então, com pudor de ser reconhecido como culpado e protegido sob a pele que o cobria, ele jazia quieto na moita. Quando Cloé, perturbada pelo que viu à primeira vista, começou a chamar Dáfnis em auxílio, os cães arrancaram a pele de cima de seu corpo e já se apoderavam dele. Com gritos lancinantes, ele suplicava ajuda à garota e a Dáfnis, que já se apresentava. Os dois acalmaram os cães rapidamente com o chamado de costume; em seguida, levaram Dórcon, que fora mordido nas coxas e nos ombros, até a fonte e lavaram-lhe as mordidas e espalharam sobre elas casca verde de olmo, depois de a mastigarem. Por sua inexperiência quanto às ousadias do amor, consideraram o uso da pele uma brincadeira pastoril e nem ficaram irritados, mas com palavras de consolo e a segurá-lo pelo braço por boa parte do caminho, se despediram dele.

[1.22] E ele, de seu lado, livre do perigo e salvo da boca do cão, não do lobo, passou a se ocupar da cura de seu corpo. Já Dáfnis e Cloé tiveram enorme trabalho até o anoitecer reunindo as cabras e as ovelhas. Apavoradas com a pele de lobo e alvoroçadas pelos latidos dos cães, umas subiram nas rochas, outras desceram rumo ao mar. Embora 
educadas a obedecer ao chamado e a se acalmar com o som da flauta e a se reunir ao batido de palmas, o medo incutiu nelas o esquecimento de tudo isso. E penosamente eles as encontraram pelos rastros, como a uma lebre, e as conduziram aos estábulos.

E apenas naquela noite dormiram um sono profundo e tiveram o cansaço como lenitivo de seus sofrimentos amorosos. Mas tão logo o dia nasceu, passaram de novo a sofrer do mesmo modo. Alegravam-se quando se viam; sofriam quando se separavam. Queriam algo - e não sabiam o que queriam. Apenas de uma coisa sabiam: que para ele o beijo tinha sido a perdição e para ela, o banho.

[1.23] Excitava-os inda mais a estação do ano. Era já fim da primavera e começo do verão e tudo estava em seu ápice: árvores com frutos, plantações com messes. $\mathrm{O}$ canto agradável das cigarras, a doce fragrância do fruto, o prazenteiro balido das ovelhas. Alguém poderia imaginar que até os rios cantavam com seu fluir sereno, que os ventos flauteavam com seu sopro sobre os pinheiros, que as maçãs caiam ao chão apaixonadas e que o sol, amante da beleza, a tudo desnudava.

Dáfnis, então, inflamado por tudo isso, lançava-se nas águas dos rios. Ora ele se banhava, ora perseguia os movimentos dos peixes. Outras vezes bebia água, na tentativa de apagar seu ardor interior. Quanto a Cloé, depois de ordenhar as ovelhas e a maioria das cabras, passava muito tempo coalhando o leite, já que, terríveis, as moscas a atormentavam e a picavam, se eram espantadas. Em seguida, depois de lavar seu rosto, coroava-se com ramos de pinheiro e circundava-se com a pela de corça. E enchendo um cálice de vinho e leite, tomava a bebida em comum com Dáfnis.

[1.24] Chegando o meio dia, já estavam presos um ao outro pelos olhos - ela, contemplando a nudez de Dáfnis, fraquejava ante sua beleza íntegra e derretia-se por não achar defeito em nenhuma parte; ele, vendo-a com a pele de corça e a guirlanda de pinheiro, a oferecer-lhe um cálice, julgava contemplar uma das Ninfas da gruta. Ele então arrebatava os ramos da cabeça dela e coroava a si mesmo, não sem antes beijar a guirlanda; ela, por sua vez, vestia a roupa dele, enquanto ele se banhava desnudo, não sem antes, também ela própria, beijá-la. Já outras vezes lançavam maçãs um no outro e, penteando as madeixas, adornavam a cabeleira um do outro. Ela comparava a cabeleira dele, que era negra, com mirtos, e ele o rosto dela, que era alvo e rosado, com maçãs. Ele também lhe ensinava a tocar a flauta - e apenas ela começava a soprar, ele próprio tomava-lhe a flauta e percorria com seus lábios os caniços. Fingindo ensinar a ela o que errara, convenientemente ele beijava Cloé por meio da flauta.

[1.25] No momento em que ele tocava flauta, ao meio dia, e os rebanhos se protegiam na sombra, Cloé sem que percebesse adormeceu. Flagrando isso e colocando de lado sua flauta, Dáfnis passou a olhar para ela inteira, insaciavelmente, sem pudor, e ao mesmo tempo sussurrando suavemente:

- Como dormem estes olhos! Como é perfumada esta boca! Nem as maçãs são assim, nem as peras. Mas não me atrevo a beijá-la - seu beijo fisga o coração, assim como o mel novo causa loucura. Receio - não vá eu despertá-la com um beijo. Oh cigarras estridentes, não deixarão que ela durma com tão alto canto! Mas até os bodes ensurdecem batendo seus chifres. Oh lobos mais covardes que raposas, que não os capturaram!

[1.26] Estava ele em tais palavras quando uma cigarra, fugindo de uma andorinha que tentava caçá-la, caiu sobre o colo de Cloé. E a andorinha que a seguia, não sendo capaz de arrebatá-la, com suas asas próximas por causa da perseguição, roçou as bochechas dela. Nada sabendo do acontecido, ela de um salto despertou de seus sonhos com altos gritos. Ao ver, porém, a andorinha ainda próxima a adejar e Dáfnis a rir por causa do susto, deixou de lado o medo e esfregou os olhos que ainda queriam 
dormir. Mas a cigarra do seu colo começou a cantar, tal qual um suplicante que reconhece a graça da salvação. De novo então Cloé gritou alto e Dáfnis riu - e aproveitando a ocasião, tocou com as mãos o busto dela e sacou dali a excelente cigarra, que nem sobre sua destra silenciava. Ela sentiu prazer ao vê-la; pegou-a, beijou-a e novamente colocou-a sobre seu colo a cantar.

[1.27] Eles se encantaram, certa vez, com uma pomba torcaz que bucólica cantava desde o bosque. E como Cloé tentasse entender o que ela dizia, eis que Dáfnis lhe ensina as coisas repetidas pelos contadores de histórias:

- Havia como você, donzela, uma bela donzela que guardava muitas vacas no bosque. Ela era também cantora e as vacas dela se deslumbravam com seu canto, tanto que ela pastoreava sem golpear com o cajado e sem agredir com o aguilhão. Ao contrário: sentada sob um pinheiro e coroada com pinha, ela cantava Pã e Pítis e, por causa de sua voz, as vacas permaneciam junto dela. Um rapaz, que não muito longe pastoreava vacas, também ele belo e cantor como a donzela, por gostar de competir com sua música, provocante ergueu sua voz, que era mais potente, por ser varão, mas também doce, por ser rapaz ainda, e oito das melhores vacas dela desviou para seu próprio gado, encantadas. A donzela então fica pesarosa pelo prejuízo de seu gado, pela derrota no canto, e roga aos deuses tornar-se um pássaro, em vez de retornar à casa. Os deuses assentem e a transformam neste pássaro aí, montanhês como a donzela, mavioso como ela era. E ainda agora com seu canto ela exibe sua desventura e busca pelas vacas desgarradas.

[1.28] Tais prazeres o verão lhes propiciava. Estando o outono em seu ápice e maduros os cachos, piratas tírios, com um barco cário, a fim de não parecer bárbaros, atracaram nos campos. E desembarcando com punhais e couraças, passaram a pilhar tudo aquilo que lhes vinha à mão, vinho com olor de flores, trigo em abundância, mel nos favos. Tangeram até algumas vacas do rebanho de Dórcon. Capturam também Dáfnis, que andava à toa pela praia - Cloé, como garota, apenas mais tarde conduzia as ovelhas de Drias, por medo dos pastores insolentes. Quando avistaram um adolescente grande e belo e mais valioso do que a pilhagem dos campos, não mais cuidaram nem das cabras nem dos outros campos. Conduziram-no até a nau, enquanto ele chorava e, no apuro, chamava alto por Cloé. Quando eles soltaram a amarra do barco e tomaram nas mãos os remos e zarparam para alto mar, nesse momento Cloé tangia seu rebanho, trazendo consigo uma flauta nova de presente para Dáfnis. Vendo as cabras agitadas e ouvindo Dáfnis gritando por ela cada vez mais forte, ela se esquece dos rebanhos e deixa cair a flauta e correndo vai até Dórcon para solicitar ajuda.

[1.29] Ele, contudo, jazia golpeado pelos piratas com feridas profundas, mal respirando, a verter muito sangue. Vendo Cloé e recobrando um pouco da antiga brasa de sua paixão, disse:

- Cloé, vou morrer em breve. Os impiedosos piratas, por eu lutar em defesa de minhas vacas, me golpearam qual a uma vaca. Salve Dáfnis, me vingue e destrua aqueles piratas. Ensinei as vacas a obedecer o som da flauta e a seguir sua música, ainda que pastem longe. Vá, tome esta flauta, entoe nela aquela música que um dia ensinei a Dáfnis e Dáfnis a você - a partir daí a flauta e as vacas que lá estão cuidarão de tudo. Para você oferto ainda esta mesma flauta, com a qual disputei e venci muitos vaqueiros e guardadores de cabras. Você, em troca, me dê um beijo enquanto ainda vivo e, depois de morto, chore por mim. E se vires outro pastoreando as minhas vacas, lembre-se de mim.

[1.30] Dórcon, de fato, disse estas palavras, acolheu com prazer o beijo derradeiro e deixou partir sua alma junto com o beijo. E Cloé, pegando da flauta e 
colocando-a em seus lábios, começou a flautear o mais alto que podia. Eis que as vacas ouvem e reconhecem a música e em um único arrebatamento, mugindo, saltam no mar. Tendo sido o pulo violento em um só lado da nau e o impacto das vacas tal que abriu o mar profundo, a nau soçobra e é destruída pelas vagas numerosas e os que se precipitam não têm todos a mesma esperança de salvação.

Os piratas, pois, estavam equipados com seus punhais e vestidos com suas couraças escamosas e calçados com grevas até o meio da perna, ao passo que Dáfnis estava descalço, como pastoreava na planície, e seminu, já que ainda era hora de calor. Depois de nadarem um pouco, então, as armas os precipitaram ao fundo. Dáfnis, contudo, despojou-se facilmente de sua roupa e esforçou-se a nadar, já que antes nadara apenas em rios; depois, por necessidade, aprendeu o que devia fazer. Lançou-se entre as vacas e segurando com as duas mãos nos chifres de duas vacas, alojou-se no meio, sem pena e sem fadiga, como se guiasse uma carroça. De fato, uma vaca nada tanto quanto nenhum homem - nisso só são vencidas pelos pássaros aquáticos e pelos próprios peixes. Um boi não se afogaria nadando, se não, por se tornarem úmidos, os cascos de suas patas não se danificassem. Testemunham este argumento até agora muitos lugares do mar, chamados passagens do boi.

[1.31] Dáfnis salva-se desta maneira e escapa, contra toda esperança, de dois perigos, pirataria e naufrágio. Ao chegar à margem e encontrar Cloé na praia a um só tempo rindo e chorando, lança-se em seu colo e quer saber o que ela pretendia ao tocar a flauta daquele jeito. Ela lhe conta tudo - a corrida até Dórcon, o adestramento das vacas, como ela foi instruída a tocar, e que Dórcon morrera. Apenas, por pudor, não falou do beijo.

Decidiram, de fato, honrar seu benfeitor e, vindo com parentes, sepultaram o infeliz Dórcon. Amontoaram então muita terra, plantaram muitas plantas domésticas e penduraram as primícias de seus próprios trabalhos, mas também libaram com leite, esmagaram cachos de uva e quebraram muitas flautas. Foram ouvidos também os mugidos piedosos das vacas e, junto com os mugidos, vistas carreiras desordenadas - e como se imaginava entre pastores de ovelhas e de cabras, era o lamento das vacas em honra ao vaqueiro que morreu.

[1.32] Depois do funeral de Dórcon, Cloé conduz Dáfnis à gruta das Ninfas e o lava. E ela própria também lavou seu corpo alvo e impoluto, devido à beleza, pela primeira vez diante dos olhos de Dáfnis, beleza que não carecia de banho algum para revelar-se. E coligindo flores quantas havia naquela estação, engrinaldaram as estátuas e penduraram a flauta de Dórcon na rocha como oferenda. Em seguida, foram examinar as cabras e as ovelhas. Estavam todas elas deitadas, sem pastar e sem balir, apenas desejando - penso eu - que Dáfnis e Cloé aparecessem. Quando então, avistados por elas, eles gritaram como de costume e tangeram as flautas, os rebanhos se levantaram e passaram a pastar e as cabras começaram a saltitar, fremindo, como se estivessem contentes com a salvação de seu pastor costumeiro.

Dáfnis, contudo, não conseguia alegrar sua alma, desde que vira a nudez de Cloé e sua beleza, antes oculta, revelada. Doía-lhe o coração, como se devorado por venenos. Às vezes a respiração lhe saía ofegante, como se alguém o perseguisse, às vezes sufocava, como se extenuada pelas incursões anteriores. E o banho dela parecia-lhe mais temível do que o mar. Julgava que sua alma estava ainda entre os piratas, como jovem que era e camponês, desconhecedor ainda da pirataria do amor.

\section{Referências}


LONGUS. Dafne e Cloé ou As pastorais. Tradução de Duda Machado. São Paulo: Princípio Editora, 1996.

LONGO. Dafnis y Cloe. AQUILES TACIO. Leucipa y Clitofonte. JÂMBLICO, Babiloníacas. Introducciones, traducciones y notas de Máximo Brioso Sánches y Emilio Crespo Güemes. Madrid: Gredos, 1997 [1982].

LONGUS. Daphnis and Cloe. PARTHENIUS. The love romances and other fragments. English translations of George Thornley, revised and augmented by John Maxwell Edmons, and S. Gaselee. London/New York: William Heinemann and G. P. Putman's Sons, 1916.

LONGUS. Erotici Scriptores Graeci, vol. 1. Rudolf Hercher. Leipzig: Teubneri, 1858. (Hospedado em Perseus Digital Library)

Data de envio: 13-03-2019

Data de aprovação: 11-05-2019

Data de publicação: 05-10-2019 